\title{
Bering Sea surface water conditions during Marine Isotope Stages 12 to 10 at Navarin Canyon (IODP Site U1345)
}

\author{
Beth E. Caissie ${ }^{1}$, Julie Brigham-Grette ${ }^{2}$, Mea S. Cook $^{3}$, and Elena Colmenero-Hidalgo ${ }^{4}$ \\ ${ }^{1}$ Iowa State University, Ames, Iowa, USA \\ ${ }^{2}$ University of Massachusetts Amherst, Amherst, Massachusetts, USA \\ ${ }^{3}$ Williams College, Williamstown, Massachusetts, USA \\ ${ }^{4}$ Universidad de León, León, Spain \\ Correspondence to: Beth E. Caissie (bethc@iastate.edu)
}

Received: 8 December 2015 - Published in Clim. Past Discuss.: 19 January 2016

Revised: 4 July 2016 - Accepted: 31 July 2016 - Published: 1 September 2016

\begin{abstract}
Records of past warm periods are essential for understanding interglacial climate system dynamics. Marine Isotope Stage 11 occurred from 425 to $394 \mathrm{ka}$, when global ice volume was the lowest, sea level was the highest, and terrestrial temperatures were the warmest of the last $500 \mathrm{kyr}$. Because of its extreme character, this interval has been considered an analog for the next century of climate change. The Bering Sea is ideally situated to record how opening or closing of the Pacific-Arctic Ocean gateway (Bering Strait) impacted primary productivity, sea ice, and sediment transport in the past; however, little is known about this region prior to $125 \mathrm{ka}$. IODP Expedition 323 to the Bering Sea offered the unparalleled opportunity to look in detail at time periods older than had been previously retrieved using gravity and piston cores. Here we present a multi-proxy record for Marine Isotope Stages 12 to 10 from Site U1345, located near the continental shelf-slope break. MIS 11 is bracketed by highly productive laminated intervals that may have been triggered by flooding of the Beringian shelf. Although sea ice is reduced during the early MIS 11 laminations, it remains present at the site throughout both glacials and MIS 11. High summer insolation is associated with higher productivity but colder sea surface temperatures, which implies that productivity was likely driven by increased upwelling. Multiple examples of Pacific-Atlantic teleconnections are presented including laminations deposited at the end of MIS 11 in synchrony with millennial-scale expansions in sea ice in the Bering Sea and stadial events seen in the North Atlantic. When global eustatic sea level was at its peak, a series of anomalous conditions are seen at U1345. We exam-
\end{abstract}

ine whether this is evidence for a reversal of Bering Strait throughflow, an advance of Beringian tidewater glaciers, or a turbidite.

\section{Introduction}

Predictions and modeling of future climate change require a detailed understanding of how the climate system works. Reconstructions of previous warm intervals shed light on interhemispheric teleconnections. The most recent interglacial period with orbital conditions similar to today was approximately $400 \mathrm{ka}$, during the extremely long interglacial known as Marine Isotope Stage (MIS) 11. $\mathrm{CO}_{2}$ concentration averaged approximately $275 \mathrm{ppm}$, which is similar to preindustrial levels (EPICA Community Members, 2004). The transition from MIS 12 into MIS 11 has been compared to the last deglaciation (Dickson et al., 2009), and extreme warmth during MIS 11 has been considered an analog for future warmth (Droxler et al., 2003; Loutre and Berger, 2003), although the natural course of interglacial warmth today has been disrupted by anthropogenic forcing (IPCC, 2013).

Despite the work done to characterize the warmth of MIS 11 in the terrestrial realm (Candy et al., 2014; Melles et al., 2012; Prokopenko et al., 2010), as well as the North Atlantic (Bauch et al., 2000; Chaisson et al., 2002; Dickson et al., 2009; Milker et al., 2013; Poli et al., 2010), little is known about this interval from the North Pacific and Bering Sea region (Candy et al., 2014). Modeling studies describe several mechanisms for linking the Atlantic and Pacific through oceanic heat transport on glacial-interglacial timescales (De- 


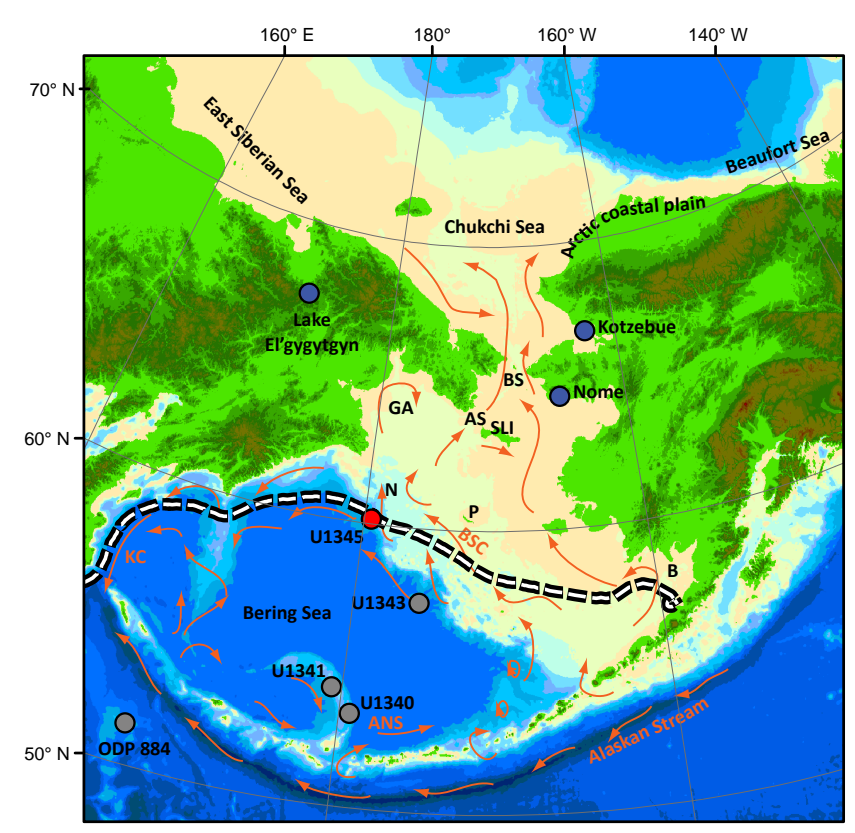

Figure 1. Map of Beringia with locations of cores mentioned in the text (U1345 (red dot), and U1340, U1341, U1343, and ODP Site 884 (grey dots)). Locations of place names from the text are labeled: Aleutian North Slope Current (ANS), Anadyr Strait (AS), Bristol Bay (B), Bering Strait (BS), Bering Slope Current (BSC), Gulf of Anadyr (GA), Kamchatka Current (KC), Navarin Canyon $(\mathrm{N})$, Pribilof Islands (P), and St. Lawrence Island (SLI). The whiteand-black dashed line is the maximum extent of sea ice (median over the period 1979-2013) (Cavalieri et al., 1996). Currents are in orange and are modified from Stabeno (1999). Base map is modified from Manley (2002).

Boer and Nof, 2004; Hu et al., 2010); however, there have been no tests of these modeling studies using proxy data older than $30 \mathrm{ka}$. Furthermore, the location of the Bering Sea marginal sea ice zone advanced and retreated hundreds of kilometers during the past three glacial-interglacial cycles (Caissie et al., 2010; Katsuki and Takahashi, 2005; Sancetta and Robinson, 1983); however, sea surface and intermediate water variability before MIS 5 is unknown.

This investigation of terrestrial-marine coupling at the shelf-slope break from MIS 12 to 10 is the first study of this interval in the subarctic Pacific (Fig. 1). We use a multi-proxy approach to examine orbital- and millennial-scale changes in productivity and sea ice extent. We demonstrate that insolation plays a major role in these changes but that sea ice also shows rapid, millennial-scale variability. Finally, we test the hypotheses that (1), in Beringia, tidewater glaciers advanced while sea level was high and (2) Bering Strait throughflow reversed shortly after the MIS 12 glacial termination (Termination $\mathrm{V}$ ). We find inconclusive evidence of a glacial advance but no evidence of Bering Strait reversal.

\section{Background}

\subsection{Global and Beringian sea level during MIS 11}

The maximum height of sea level during MIS 11 is an open question with estimates ranging from 6 to $13 \mathrm{~m}$ above present sea level (a.p.s.1.) (Dutton et al., 2015) to $0 \mathrm{~m}$ a.p.s.l. (Rohling et al., 2010; Rohling et al., 2014). The discrepancy may stem from large differences between global eustatic (Bowen, 2010) or ice-volume averages (McManus et al., 2003) and regional geomorphological or micropaleontological evidence (van Hengstum et al., 2009). Regional isostatic adjustment due to glacial loading and unloading is now known to be significant, and regional highstands may record higher than expected sea levels if glacial isostasy and dynamic topography have not been accounted for, even in places that were never glaciated (PAGES Past Interglacials Working Group, 2016; Raymo and Mitrovica, 2012; Raymo et al., 2011). For example, Raymo and Mitrovica (2012) suggest eustatic sea level during MIS 11 was 6-13 ma.p.s.l. globally and near $5 \mathrm{~m}$ a.p.s.l. locally in Beringia, yet MIS 11 shorelines are at $+22 \mathrm{~m}$ today in northwestern Alaska (Kaufman and Brigham-Grette, 1993) due to these complex geophysics.

Regardless of the ultimate height of sea level, the transition from MIS 12 to MIS 11 records the greatest change in sea level of the last $500 \mathrm{ka}$ (Rohling et al., 2014); sea level rose from perhaps $-140 \mathrm{~m}$ to its present level or higher (Bowen, 2010; Dutton et al., 2015). Sea level history during MIS 11 may have been complex (Kindler and Hearty, 2000), but most records agree that sea level during this exceptionally long interglacial (30 kyr) was highest from 410 to $401 \mathrm{ka}$, coincident with a second peak in June insolation at $65^{\circ} \mathrm{N}$. This long highstand most likely requires partial or complete collapse of the Greenland Ice Sheet (up to $6 \mathrm{~m}$ ) (de Vernal and HillaireMarcel, 2008; Reyes et al., 2014) and/or the West Antarctic Ice Sheet (Scherer et al., 1998), but not the East Antarctic Ice Sheet (PAGES Past Interglacials Working Group, 2016; Dutton et al., 2015; Raymo and Mitrovica, 2012). It has frequently been hypothesized that the West Antarctic Ice Sheet collapsed during MIS 11, and modeling studies confirm this (Pollard and DeConto, 2009); however, unconformities in the record prevent confirmation of a collapse (McKay et al., 2012). Yet, Teitler (2015) show that ice-rafted debris (IRD) during MIS 11 dropped as low as it was during MIS 31, when it is clear that the West Antarctic Ice Sheet had collapsed (Naish et al., 2009). With uncertainties, East Antarctic ice was stable; however, small changes in either sector of the Antarctic Ice Sheet may have contributed up to $5 \mathrm{~m}$ of sea level rise (PAGES Past Interglacials Working Group, 2016; EPICA Community Members, 2004).

The sea level history of Beringia defines Arctic communication between the Pacific and the Atlantic oceans during the Plio-Pleistocene. As a region, Beringia consists of both the terrestrial and marine realms north of the Aleutian Islands that stretch to the shelf-slope break in the Bering, 

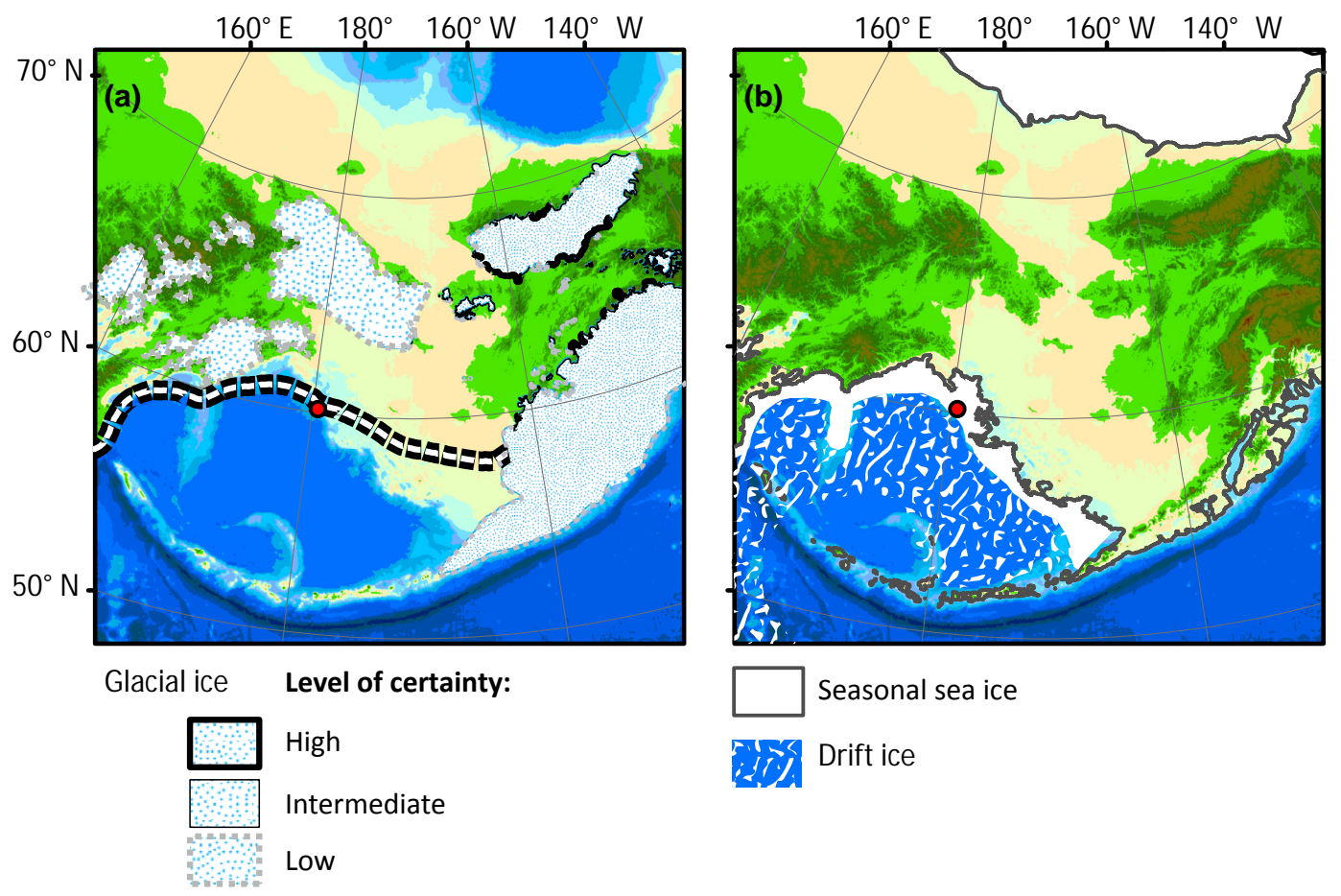

Q Modern sea ice maximum

Figure 2. Maximum glacial and sea ice extents in Beringia. Panel (a) depicts the maximum glacial ice in Beringia as inferred from terminal and lateral moraines (Gualtieri et al., 2000; Heiser and Roush, 2001; Kaufman, et al., 2011; Barr and Clark, 2009). This is not intended to show the maximum extent during a particular glaciation but rather the maximum possible extent of glacial ice. These moraines are likely from several different major glaciations. The level of certainty is indicated by the thickness of the line at the moraine. The white-and-black dashed line is the maximum extent of sea ice (median over period 1979-2013) (Cavalieri et al., 1996). Panel (b) depicts the approximate pattern of sea ice during glacial stages (Katsuki and Takahashi, 2005). The dark-grey contour is -140 m a.p.s.l., the approximate sea level during MIS 12 (Rohling et al., 2010). Base map is modified from Manley (2002).

East Siberian, Chukchi, and Beaufort seas (Fig. 1). On land, Beringia extends from the Lena River in Siberia to the Mackenzie River in Canada. Large portions of the Beringian shelf were exposed when sea level dropped below $-50 \mathrm{~m}$ (Hopkins, 1959), and this subaerial expanse stretches more than $1000 \mathrm{~km}$ from north to south during most glacial periods (Fig. 2). In contrast, as sea level rises at glacial terminations, the expansive continental shelf is flooded rapidly once sea level reaches $-60 \mathrm{~m}$ a.p.s.l. (Keigwin et al., 2006). This introduces fresh organic matter and nutrients into the southern Bering Sea (i.e., Bertrand et al., 2000; Shiga and Koizumi, 2000; Ternois et al., 2001), re-establishing at $-50 \mathrm{~m}$ a.p.s.l. the connection between the Pacific and Atlantic oceans through Bering Strait (Keigwin et al., 2006). The late Cenozoic history of the depth of the Bering Strait sill is poorly known; hence, current oceanographic reconstructions (e.g., Knudson and Ravelo, 2015) assume that a sill depth of $-50 \mathrm{~m}$ a.p.s.l. was temporally stable, which is probably not the case and requires future study. However, in this study, we also assume that a sill depth of $-50 \mathrm{~m}$ a.p.s.l. controls oceanographic communication between the Atlantic and $\mathrm{Pa}$ cific oceans.

\subsection{Site location and oceanographic setting}

The Integrated Ocean Drilling Program's (IODP) Expedition 323, Site U1345, is located on an interfluve ridge near the shelf-slope break in the Bering Sea (Fig. 1). Navarin Canyon, one of the largest submarine canyons in the world (Normack and Carlson, 2003), is located just to the northwest of the site. Sediments were retrieved from $\sim 1008 \mathrm{~m}$ of water, placing the site within the center of the modern-day oxygen minimum zone (Takahashi et al., 2011). We focus on this site because of its proximity to the modern marginal ice zone in the Bering Sea and observed high sedimentation rates. Its siting on top of an interfluve was chosen to reduce the influence of turbidites moving through Navarin Canyon.

Today, water circulates cyclonically in the deep basins of the Bering Sea (Fig. 1). Site U1345 is influenced by the northwest-flowing Bering Slope Current (BSC), which is derived from the Alaskan Stream (AS). South of the Aleutians Islands, the Alaskan Stream flows westward and enters the 
Table 1. Age-depth tie points used in the age model for U1345.

\begin{tabular}{rrl}
\hline $\begin{array}{r}\text { Depth } \\
(\mathrm{m} \text { CCSF-A) }\end{array}$ & $\begin{array}{r}\text { Age } \\
(\mathrm{ka})\end{array}$ & Date type \\
\hline 98.6 & 337 & Foraminifera (Cook, 2016) \\
115.3 & 374 & Foraminifera (Cook, 2016) \\
123.2 & 398.5 & Magnetic susceptibility correlation \\
130.6 & 424 & Foraminifera (Cook, 2016) \\
148.7 & 478 & Foraminifera (Cook, 2016) \\
\hline
\end{tabular}

Bering Sea through deep channels in the western Aleutian Islands. Once north of the Aleutian Islands, this water mass becomes the Aleutian North Slope Current (ANS), and flows eastward until it reaches the Bering Sea shelf. Interactions with the shelf turn this current to the northwest, where it becomes the Bering Slope Current (Stabeno et al., 1999). Tidal forces and eddies in the Bering Slope Current drive upwelling through Navarin Canyon and other interfluves along the shelf-slope break (Kowalik, 1999). The resulting cold water and nutrients brought to the sea surface, coupled with the presence of seasonal sea ice, drive the high productivity found today in the so-called "Green Belt" (Springer et al., 1996) along the shelf-slope break. North of the site, lowsalinity, high-nutrient shelf waters (Cooper et al., 1997) primarily flow north through the Bering Strait to the Arctic Basin (Schumacher and Stabeno, 1998).

\section{Methods}

\subsection{Age model}

The age model (Fig. 3) is derived from the shipboard age model, which was developed using magnetostratigraphy and biostratigraphy. First and last appearance datums for diatoms and radiolarians make up the majority of the biostratigraphic markers used to place the record in the correct general stratigraphic position (Takahashi et al., 2011). Oxygen isotope measurements taken on the benthic foraminifera, Uvigerina peregrina, Nonionella labradorica, and Globobulimina affinis (Cook et al., 2016) were then used to tune site U1345 to the global marine benthic foraminiferal isotope stack (LR04) (Lisiecki and Raymo, 2005) (Fig. 3; Table 1). Based on this combined age model, MIS 11 spans from 115.3 to $130.6 \mathrm{mbsf}$ (Cook et al., 2016); however, the characteristic interglacial isotopic depletion was not found in U1345, which means that the exact timing of peak interglacial conditions is unknown.

The nearby core from Site U1343 of IODP Expedition 323 (Fig. 1) has an excellent oxygen isotopic record during MIS 11 (Asahi et al., 2016). We compared the two isotopic records and their magnetic susceptibilities (Fig. 3) and found that, even with only two tie points, there was good correlation between the timing of the onset of laminated intervals and also the interglacial increase in magnetic susceptibility (Fig. 3b). We added one additional tie point to connect the in- flection points in magnetic susceptibility (Table 1). In U1343, this point occurred at $398.50 \mathrm{ka}$. U1345 was shifted $1.5 \mathrm{ka}$ younger in order to align with U1343. The addition of this point allows us to have more confidence in the timing of peak interglacial conditions in U1345. However, given the oxygen isotope sampling resolution, as well as the stated error in the LR04 dataset (4 kyr), we estimate the error of the age model could be up to $5 \mathrm{kyr}$. Therefore, we urge caution when comparing millennial-scale changes at this site with other sites that examine MIS 11 at millennial-scale resolution or finer.

Sedimentation rates during the study interval range from 29 to $45 \mathrm{~cm} \mathrm{kyr}^{-1}$, with the highest sedimentation rates occurring during glacial periods. Depths and ages of major climate intervals referred to in the text are found in Table 2.

\subsection{Sediment analyses}

Details about sediment sampling can be found in the Supplement. Quantitative diatom slides were prepared (Scherer, 1994) and counted (Schrader and Gersonde, 1978) using published taxonomic descriptions and images (Hasle and Heimdal, 1968; Koizumi, 1973; Lundholm and Hasle, 2008, 2010; Medlin and Hasle, 1990; Medlin and Priddle, 1990; Onodera and Takahashi, 2007; Sancetta, 1982, 1987; Syvertsen, 1979; Tomas, 1996; Witkowski et al., 2000). Diatom taxa were then grouped according to ecological niche (Table 3) based on biological observations (Aizawa et al., 2005; Fryxell and Hasle, 1972; Håkansson, 2002; Horner, 1985; Saito and Taniguchi, 1978; Schandelmeier and Alexander, 1981; von Quillfeldt, 2001; von Quillfeldt et al., 2003) and statistical associations (Barron et al., 2009; Caissie et al., 2010; Hay et al., 2007; Katsuki and Takahashi, 2005; Lopes et al., 2006; McQuoid and Hobson, 2001; Sancetta, 1982, 1981; Sancetta and Robinson, 1983; Sancetta and Silvestri, 1986; Shiga and Koizumi, 2000). In cases where a diatom species was reported to fit into more than one environmental niche, it was grouped into the niche where it was most commonly recognized in the literature.

Eighteen quantitative calcareous nannofossil slides were prepared (Flores and Sierro, 1997) and counted using a Zeiss polarized light microscope at $1000 \times$ magnification. Samples were considered barren if no coccoliths were found in at least 165 randomly selected fields of view. All taxa were identified to the species or variety level (Flores et al., 1999; Young et al., 2003).

Grain size of both biogenic and terrigenous sediment was measured using a Malvern Mastersizer 3000 with the Hydro MV automated wet dispersion unit. The mineralogy of 10 samples was analyzed using a Siemens D-5000 X-ray diffractometer (Eberl, 2003).

The carbon and nitrogen isotopic and elemental composition of organic matter was determined by Dumas combustion using a Carlo Erba 1108 elemental analyzer coupled to a Thermo Finnigan Delta Plus XP isotope ratio mass spectrometer at the University of California Santa Cruz Stable Isotope 
(a)
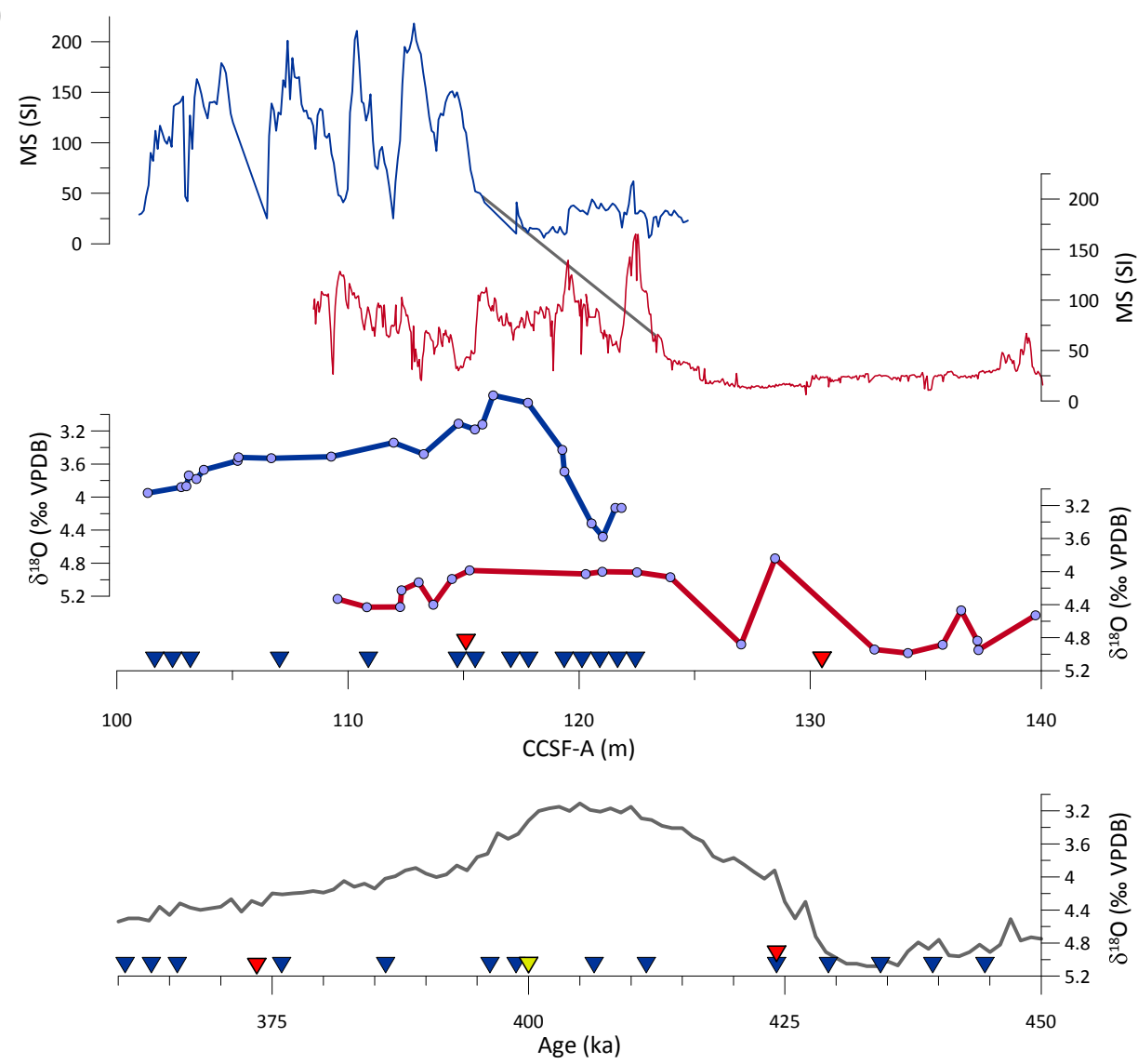

(b)

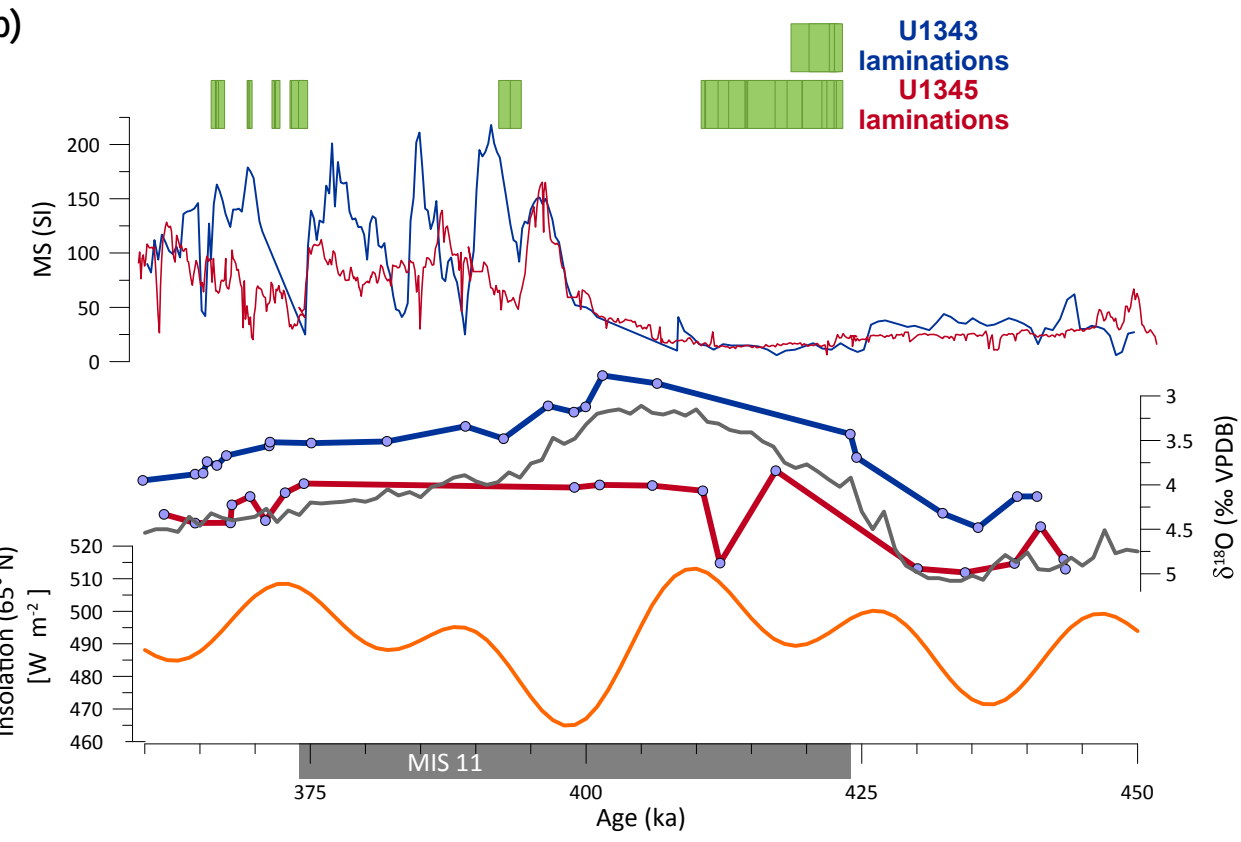

Figure 3. (a) Age model plotted by depth. Blue plots depict data from Site U1343, while red plots are from U1345. Magnetic susceptibility and benthic foraminiferal $\delta^{18} \mathrm{O}$ are plotted by depth for each site in the top half of the figure. The grey line joining the magnetic susceptibility plots indicates the tie point that was added in this study. Inverted triangles indicate locations of tie points (red: U1345; blue: U1343; grey: magnetic susceptibility) between Bering Sea $\delta^{18} \mathrm{O}$ (Cook et al., 2016; Asahi et al., 2016) and the global marine stack (Lisiecki and Raymo, 2005), which is plotted in grey. (b) Age model plotted by age. Magnetic susceptibility and $\delta^{18} \mathrm{O}$ are shown with the global marine $\delta^{18} \mathrm{O}$ stack (grey) and insolation at $65^{\circ} \mathrm{N}$ (orange). Green bars indicate laminated intervals in U1343 and U1345. 
Table 2. Depths and ages of major climate intervals referred to in the text.

\begin{tabular}{lrrrr}
\hline Interval & $\begin{array}{r}\text { Depth beginning } \\
(\mathrm{m} \text { CCSF-A) }\end{array}$ & $\begin{array}{r}\text { Depth end } \\
(\mathrm{m} \mathrm{CCSF}-\mathrm{A})\end{array}$ & $\begin{array}{r}\text { Beginning } \\
(\mathrm{ka})\end{array}$ & $\begin{array}{r}\text { End } \\
(\mathrm{ka})\end{array}$ \\
\hline Late MIS 11/10 & 121.80 & 110.57 & 394 & 364 \\
Anomalous interval & 124.94 & 121.80 & 405 & 394 \\
Peak MIS 11 & 130.16 & 121.80 & 423 & 394 \\
Termination V & 131.09 & 130.16 & 425 & 423 \\
MIS 12 & 133.10 & 131.09 & 431 & 425 \\
\hline
\end{tabular}

Table 3. Bering Sea diatom species grouped by environmental niche. In cases where a species appears in more than one niche, the grouping used in this study is highlighted in bold.

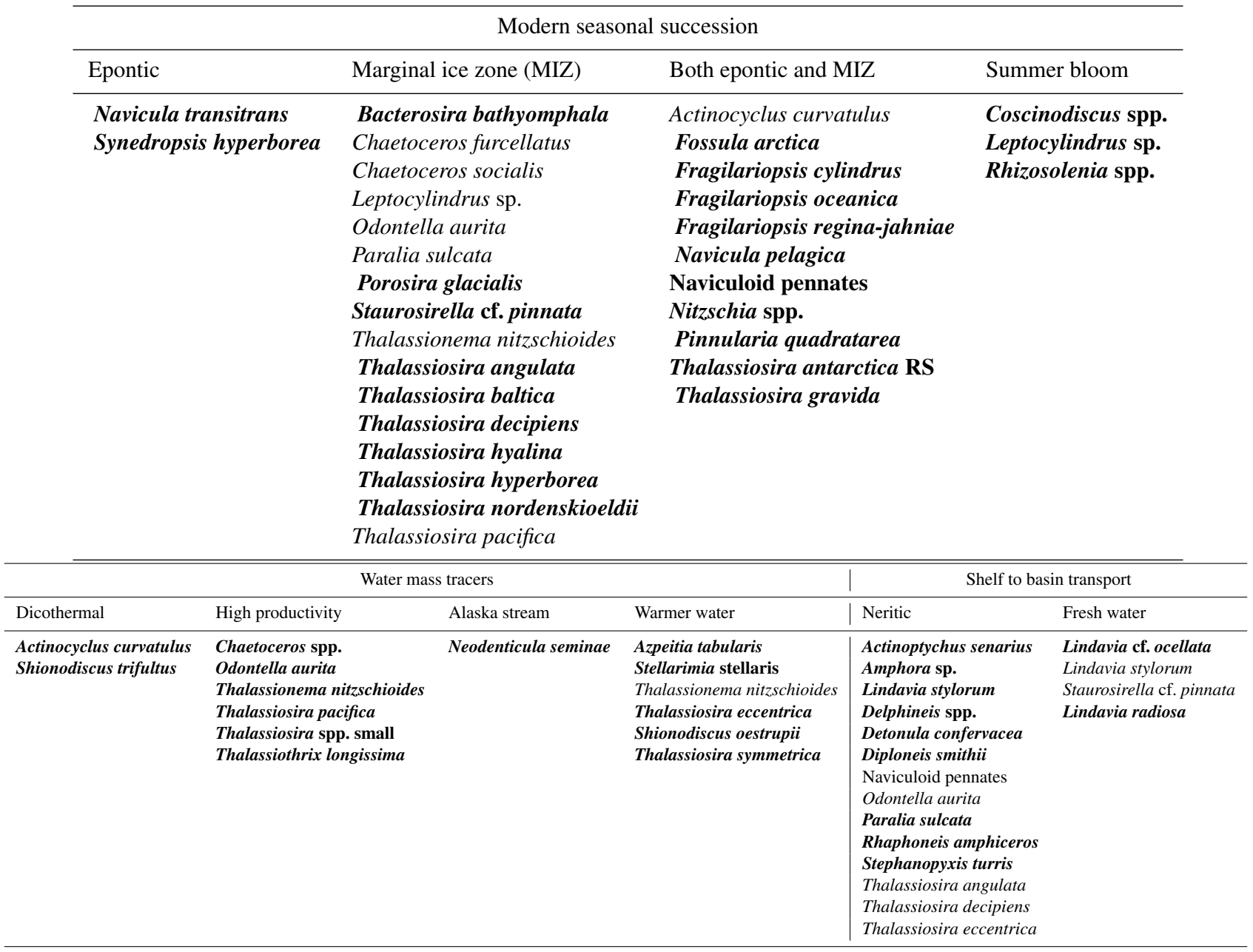

Laboratory. The $1 \sigma$ precision of stable isotope measurements and elemental composition of carbon is $0.2 \%$ and $0.03 \%$, respectively, and $0.2 \%$ and $0.002 \%$, respectively, for nitrogen. $\delta^{13} \mathrm{C}$ values are reported relative to the Vienna Pee Dee Belemnite (VPDB) and $\delta^{15} \mathrm{~N}$ values are reported relative to atmospheric $\mathrm{N}_{2}$. Percent $\mathrm{CaCO}_{3}$ was calculated according to Schubert and Calvert (2001). More detailed methodology can be found in the Supplement.

\section{Results}

\subsection{Sedimentology}

The sediments at Site U1345 are massive with centimeterscale dark or coarse-grained mottles. They are mainly composed of clay and silt with varying amounts of diatoms, sand, and tephra throughout. Laminated intervals bracket MIS 11 (Fig. 4). The proportion of diatoms relative to terrigenous 
or volcanogenic grains is highest during laminated intervals and lowest immediately preceding Termination $\mathrm{V}(\sim 425 \mathrm{ka})$. Vesiculated tephra shards were seen in every diatom slide analyzed. Several thin $(<1 \mathrm{~cm})$ sand layers and shell fragments were visible on the split cores, especially during MIS 12. However, high-resolution grain size analyses show that the median grain size was lowest during MIS 12, increasing from approximately 14 to $21 \mu \mathrm{m}$ at the start of Termination $\mathrm{V}$ at $424.5 \mathrm{ka}$ (130.92 m b.s.f.). Median grain size peaks at $84 \mu \mathrm{m}$ between 401 and $407 \mathrm{ka}$ (125.42-123.62 m b.s.f.). This interval is also the location of an obvious sandy layer in the core. After this "anomalous interval", median grain size remains steady at about $17 \mu \mathrm{m}$. Subrounded to rounded clasts (granule to pebble) commonly occur on the split surface of the cores. We combined clast and sand layer data from all holes at Site U1345 when examining their distribution (Fig. 4).

A $3.5 \mathrm{~m}$ thick laminated interval, estimated to span $12 \mathrm{kyr}$ (see Table 4 for depths and ages), is deposited beginning during Termination V. Although the termination is short-lived and the laminated interval quite long, we refer to it as the Termination V Laminations for the sake of clarity throughout this manuscript. The next laminated interval occurs at about $394 \mathrm{ka}$ and lasts approximately $1.1 \mathrm{kyr}$. During the transition from late MIS 11 to MIS 10, a series of four thin laminated intervals are observed. Each interval lasts between 0.34 and $1.25 \mathrm{ka}$ (Table 4). In general, the upper and lower boundaries of laminated intervals are gradational; however, the boundaries between individual lamina are sharp (Takahashi et al., 2011). There are two types of laminations. The Termination V Laminations are type I laminations: millimeter-scale alternations of black, olive-grey, and light-brown triplets. In addition to containing a high proportion of diatoms, this type of laminated interval also contains high relative proportions of calcareous nannofossils and foraminifera (Takahashi et al., 2011). The majority of laminations are parallel; however, a $7 \mathrm{~cm}$ interval during the Termination V Laminations is highly disturbed in Hole A, showing recumbent folds in the laminations (Takahashi et al., 2011). This interval was not sampled. Type II laminations occur throughout the remainder of MIS 11. These laminations have fewer diatoms and tend to be couplets of siliciclastic sediments with $<40 \%$ diatoms (Takahashi et al., 2011). Percent $\mathrm{CaCO}_{3}$ also increases during these laminations though foraminifera and calcareous nannofossils are very rarely seen. None of these later laminated intervals contain any evidence of disturbance.

\subsection{Mineralogy}

We determined the weight percent of 23 common minerals in 10 samples across the study interval. Samples are primarily composed of quartz, plagioclase, tephra, illite, and chlorite with minor amounts of other clay and non-clay minerals (Table 5). Downcore, the largest variability occurs in the weight percent of quartz, chlorite, and illite. In general, chlorite comprises nearly $35 \%$ of the minerals present in the sedi-

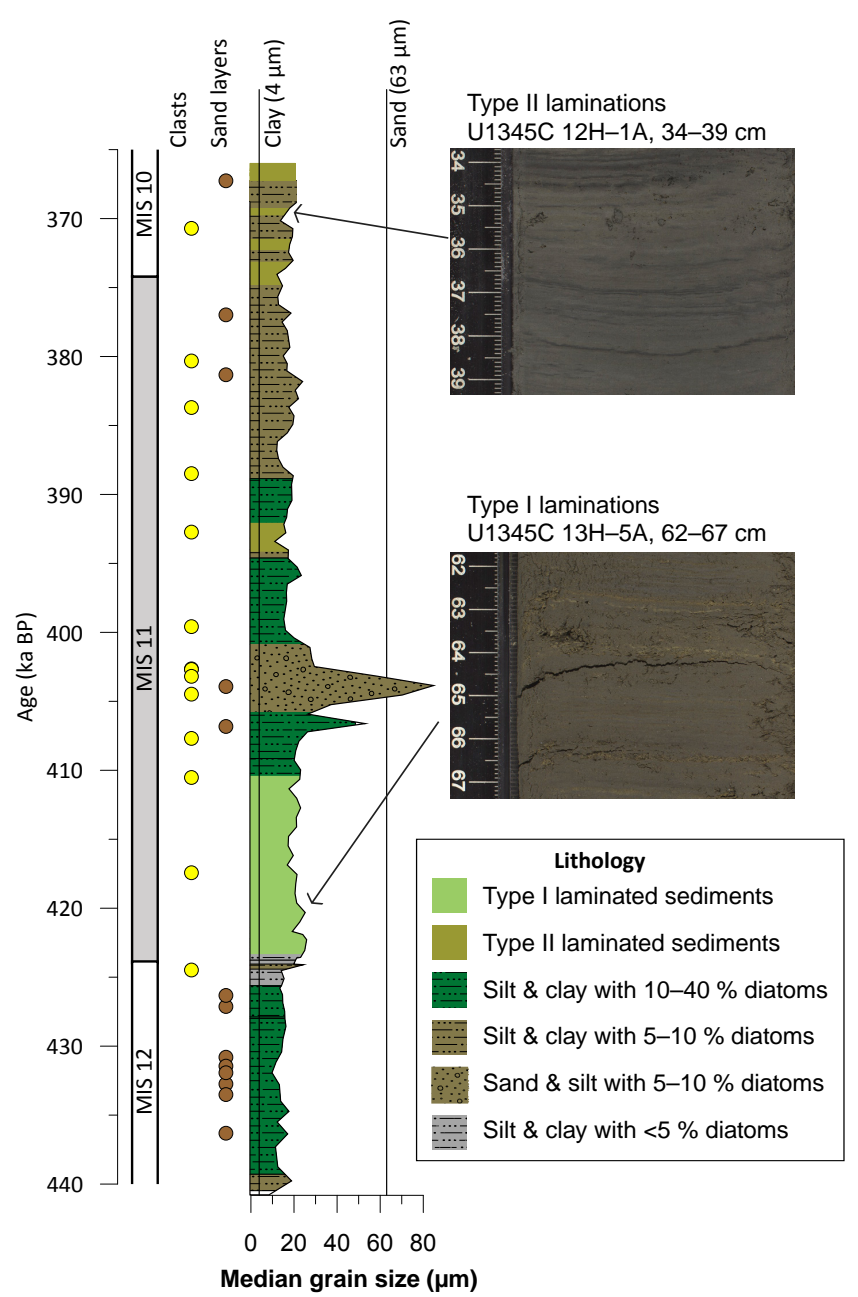

Figure 4. Lithostratigraphic column for U1345A. Marine Isotope Stage 11 is depicted as a grey bar. Ice-rafted debris (yellow dots) and sand layers (brown dots) are a compilation of these features in all four holes at U1345. The width of the lithologic column varies according to median grain size. Vertical lines indicate the cut-off for clay- and sand-sized particles. Silt lies between the two lines. Colors depict varying amounts of diatoms relative to terrigenous grains in the sediment. Type I laminations are depicted as pale-green bars and type II laminations are depicted as olive-green bars. An example of each of the lamination types is shown in the images to the right.

ments until $399 \mathrm{ka}$, and then declines $\sim 5 \%$ for the remainder of MIS 11. Conversely, quartz increases from 422 to $397 \mathrm{ka}$ and then comprises $\sim 15 \%$ of the minerals for the remainder of MIS 11 . Illite is lower than $2 \%$ of the mineral assemblage at $424 \mathrm{ka}$, and then increases rapidly to nearly $10 \%$ at $422 \mathrm{ka}$. It remains near $10 \%$ for the remainder of MIS 11 except for a brief negative excursion at $397 \mathrm{ka}$. 
Table 4. Distribution of laminated intervals during MIS 11. Note that the depth and age of laminated intervals encompasses all holes drilled, but the median duration is calculated using each of the holes that it is present in.

\begin{tabular}{llllrl}
\hline Lamination & Type & Depth & Age & $\begin{array}{r}\text { Median } \\
\text { duration } \\
(\mathrm{kyr})\end{array}$ & $\begin{array}{l}\text { Found } \\
\text { in holes }\end{array}$ \\
\hline MIS 11.5 & II & $112.02-111.47$ & $367.23-366.00$ & 0.51 & CDE \\
MIS 11.4 & II & $113.14-112.94$ & $369.72-369.26$ & 0.34 & CD \\
MIS 11.3 & II & $114.28-113.95$ & $372.25-371.52$ & 0.73 & D \\
MIS 11.2 & II & $115.59-114.69$ & $374.75-373.17$ & 1.23 & ACE \\
MIS 11.1 & II & $121.84-121.18$ & $394.12-392.09$ & 1.10 & CE \\
Termination V & I & $130.23-126.51$ & $423.28-410.44$ & 12.04 & ACDE \\
\hline
\end{tabular}

\subsection{Diatoms}

\subsubsection{Diatom assemblages}

A total of 97 different diatom taxa were identified. Individual samples include between 26 and 46 taxa each with an average of 37 taxa. Both types of laminated intervals contain fewer taxa than bioturbated intervals do. This decrease in diversity is confirmed using the Margalef, Simpson, and Shannon indices (Maurer and McGill, 2011), which all show similar downcore profiles (Fig. 5). The Margalef index is a measure of species richness. It shows a decrease in the number of taxa during four out of five laminated intervals that are sufficiently well sampled. Between laminated intervals, there is also a noted decrease in taxa at $388 \mathrm{ka}$. The Simpson index measures the evenness of the sample. Values close to 1 indicate that all taxa contain an equal number of individuals, while values close to 0 indicate that one species dominates the assemblage. In general, the Simpson index is close to 1 throughout the core; however, during the Termination $\mathrm{V}$ Laminations and the most recent two laminations, the Simpson index decreases reflecting the dominance by Chaetoceros resting spores (RS) during these intervals (Fig. 5). The Simpson index never approaches 0 , which would likely indicate a strong dissolution signal. The Shannon diversity index measures both species richness and evenness. Correspondingly, it is low during three of the laminated intervals and high during MIS 12, and peaks at $397 \mathrm{ka}$ (Fig. 5).

Absolute diatom abundances vary between $10^{6}$ and $10^{8}$ diatoms deposited per gram of sediment with values an order of magnitude higher during most laminated intervals than during massive intervals (Fig. 5). The diatom assemblage is dominated by Chaetoceros and Thalassiosira antarctica RS, with lesser contributions from Fragilariopsis oceanica, F. cylindrus, Fossula arctica, Shionodiscus trifultus $(=$ T. trifulta), T. binata, small ( $<10 \mu \mathrm{m}$ in diameter) $T$. species, Paralia sulcata, Lindavia cf. ocellata, Neodenticula seminae, and Thalassionema nitzschioides (Fig. 6).

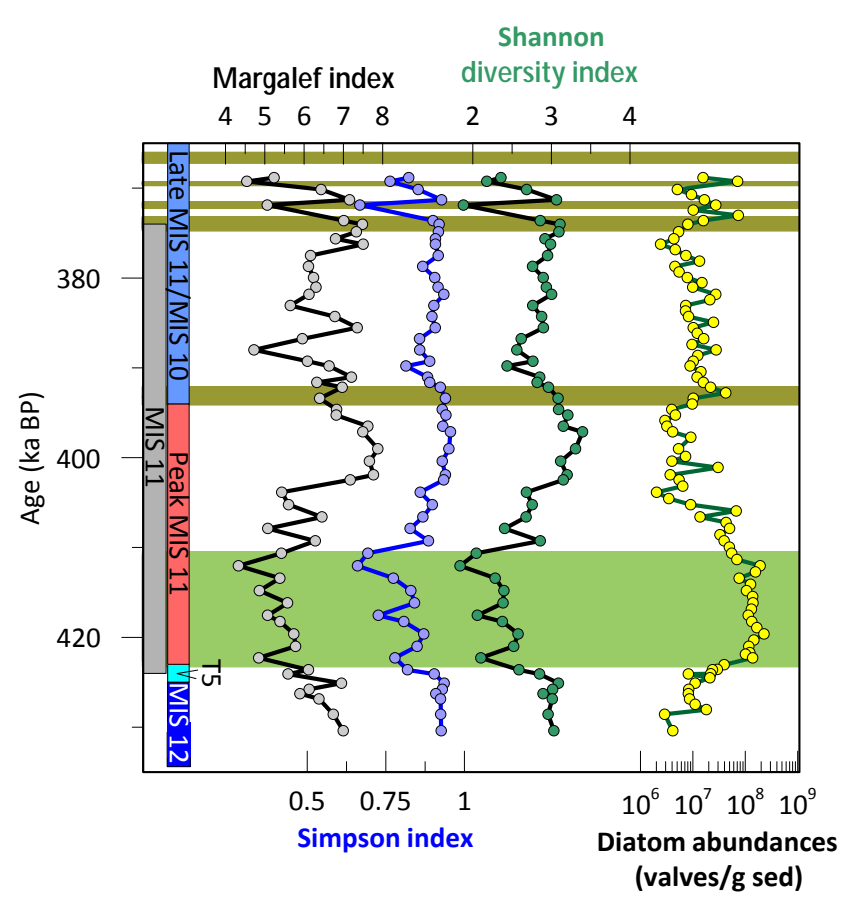

Figure 5. The Margalef, Simpson, and Shannon diversity indices plotted with diatom abundances. Type I laminations are depicted as pale-green bars and type II laminations are depicted as olive-green bars. Colored vertical bars refer to the zones mentioned in the text.

\subsubsection{Qualitative diatom proxies}

Diatoms, like many organisms, thrive under a specific range of environmental conditions or optima that are different for each species. For this reason, diatom assemblages are excellent paleoceanographic indicators (Smol, 2002). We grouped diatoms with similar environmental niches together (Table 3) to interpret the paleoceanographic sea surface conditions at the Bering Sea shelf-slope break during MIS 12 to 10 (Caissie, 2012; Caissie and Nesterovich, personal communication, 2016; Katsuki and Takahashi, 2005; Sancetta, 1982) (Fig. 7). Grouping diverse species together may result in a loss of information when two different species in the same 
Table 5. Summary statistics for X-ray diffraction.

\begin{tabular}{|c|c|c|c|c|}
\hline & Mean & Standard deviation & Minimum & Maximum \\
\hline Full pattern degree of fit: & 0.257 & 0.014 & 0.242 & 0.282 \\
\hline Mineral & $($ wt $\%)$ & (wt \%) & (wt \%) & $($ wt $\%)$ \\
\hline \multicolumn{5}{|l|}{ Non-clays } \\
\hline Quartz & 14 & 2 & 9 & 16 \\
\hline K-spar & 1 & 1 & 0 & 2 \\
\hline Plag & 9 & 2 & 5 & 12 \\
\hline Calcite & $\operatorname{Tr}$ & $\operatorname{Tr}$ & 0 & 1 \\
\hline Aragonite & 2 & 1 & 0 & 3 \\
\hline Dolomite & 2 & 1 & 1 & 3 \\
\hline Siderite & 1 & 1 & 0 & 2 \\
\hline Amphibole & 4 & 1 & 3 & 5 \\
\hline Pyroxene & 1 & 1 & 0 & 2 \\
\hline Pyrite & 1 & 0 & 0 & 1 \\
\hline Magnetite & $\operatorname{Tr}$ & $\operatorname{Tr}$ & 0 & 1 \\
\hline Hematite & $\operatorname{Tr}$ & $\operatorname{Tr}$ & 0 & 1 \\
\hline Goethite & $\operatorname{Tr}$ & $\operatorname{Tr}$ & 0 & 0 \\
\hline Maghemite & $\operatorname{Tr}$ & $\operatorname{Tr}$ & 0 & 1 \\
\hline Titanite & 1 & 1 & 0 & 3 \\
\hline Tephra & 21 & 5 & 16 & 35 \\
\hline Zircon & $\operatorname{Tr}$ & $\operatorname{Tr}$ & 0 & 0 \\
\hline Total non-clays & 57 & 2 & 54 & 63 \\
\hline \multicolumn{5}{|l|}{ Clays } \\
\hline Kaolinite & 0 & 0 & 0 & 0 \\
\hline Smectite & 0 & 0 & 0 & 0 \\
\hline Illite & 8 & 3 & 2 & 11 \\
\hline Biotite & 2 & 1 & 0 & 3 \\
\hline Chlorite & 33 & 3 & 29 & 38 \\
\hline Muscovite & $\operatorname{Tr}$ & 1 & 0 & 2 \\
\hline Total clays & 43 & 2 & 37 & 46 \\
\hline Total & 100 & & & \\
\hline
\end{tabular}

niche show differing abundance patterns over time. On the other hand, changes in abundances may simply reflect different species filling the same niche at different times.

Chaetoceros RS are the dominant taxa included in the high-productivity group (Table 3 ). Relative percent abundances of Chaetoceros RS are highest (up to 69\%) during the Termination $\mathrm{V}$ Laminations and follow the pattern of both diatom accumulation rate (Fig. 7c) and insolation at $65^{\circ} \mathrm{N}$ (Berger and Loutre, 1991). The lowest relative abundances (15-20\%) of Chaetoceros/high-productivity species occur between 403 and $390 \mathrm{ka}$ (124.21 to $120.07 \mathrm{~m}$ b.s.f.), when both obliquity and insolation are low (Fig. 7h).

Epontic diatoms are those that bloom attached to the underside of sea ice or within brine channels in the ice (Alexander and Chapman, 1981). This initial bloom occurs below the ice as soon as enough light penetrates to initiate photosynthesis in the Bering Sea, which can occur as early as March
(Alexander and Chapman, 1981). A second ice-associated bloom occurs as sea ice begins to break up on the Bering Sea shelf. This bloom is referred to as the marginal ice zone bloom and many of its members are common species in the sediment assemblage. Several diatom species are present in both types of sea ice blooms, and so while they are indicators of ice presence, they cannot be used to distinguish between types of sea ice. These species are grouped under "both ice types" (Table 3 ).

Epontic species are present in very low relative percent abundances $(<1 \%)$ throughout much of the record only when freshwater diatoms increase (Fig. 7i, n). Marginal ice zone species fluctuate between 4 and $14 \%$ throughout the record and do not show any trends in abundance changes (Fig. 7j). The grouping of species found both within the ice and in the water surrounding ice, however, is somewhat reduced during laminated intervals (Fig. 7k). 


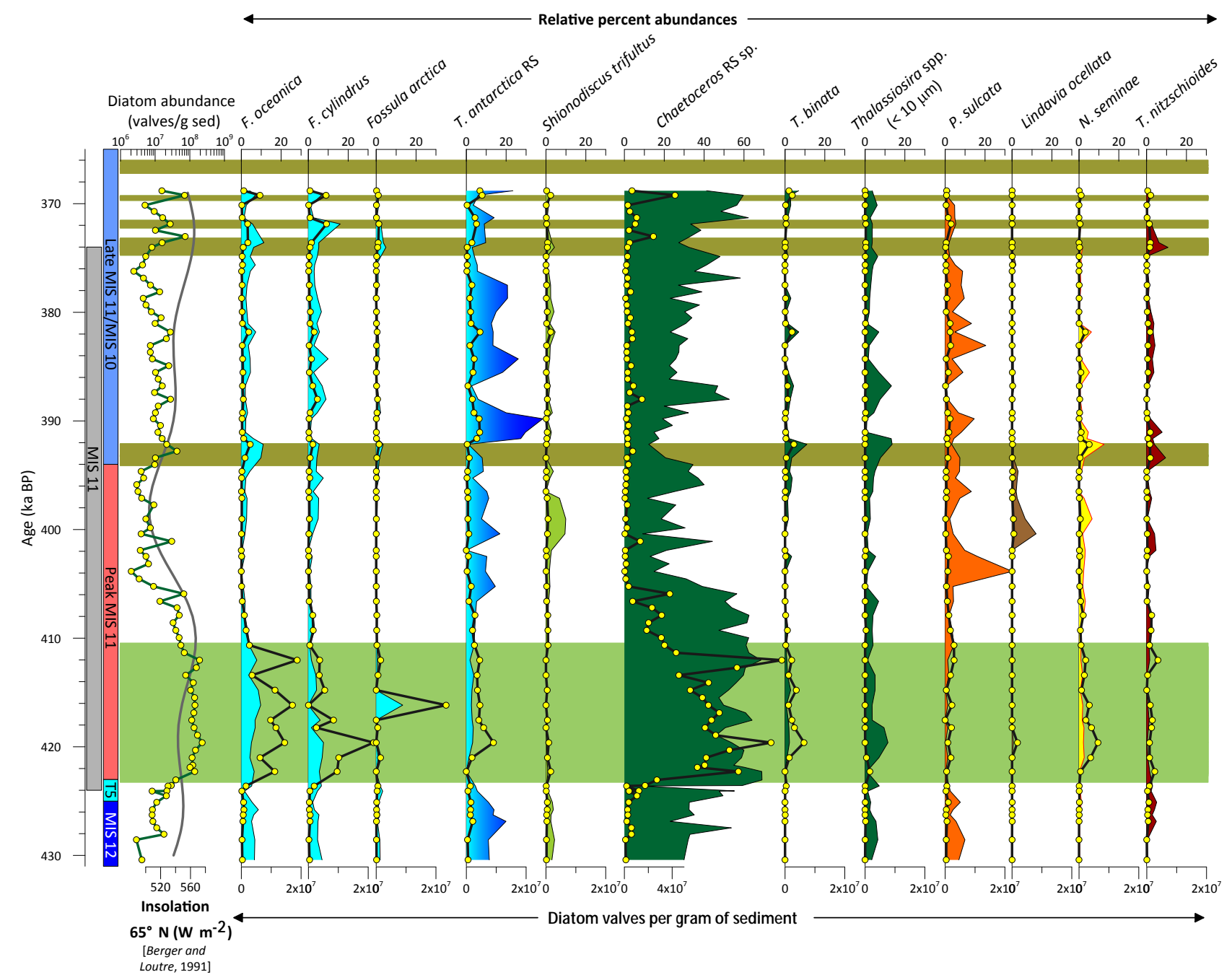

Figure 6. Absolute and relative percent abundances of all diatoms that occur in abundances greater than $10 \%$ of any assemblage. Colored vertical bars refer to the zones mentioned in the text. Line plots depict absolute abundance and area plots depict relative percent abundance. Species are color-coded according to the niche that they are grouped into: marginal ice zone (light blue), both ice types (dark blue to light blue), dicothermal (light green), high productivity (green), neritic (orange), freshwater (brown), North Pacific (yellow), and warm water (red). Insolation at $65^{\circ} \mathrm{N}$ (light-grey line) is also shown. Type I laminations are depicted as pale-green bars and type II laminations are depicted as olive-green bars.

A cold layer of water found between seasonally warmer surface and warmer deep water characterizes dicothermal water. It is stable because of its very low salinity. In the Sea of Okhotsk and the Bering Sea today, the dicothermal layer is associated with melting sea ice. Genera present in the Bering Sea during late summer tend to covary with the dicothermal water indicators, so the two groups were merged for comparison with other diatom groups. S. trifultus is the dominant species in the dicothermal group (Table 3). It is relatively high $(\sim 4 \%)$ during MIS 12 , is virtually absent from the sediments during the Termination V Laminations, and then increases again until it peaks at $10 \%$ relative abundance at $400 \mathrm{ka}$ (123.22 m b.s.f.) (Fig. 6).
Neritic species maintain $\sim 10 \%$ relative abundance throughout the core (Fig. $7 \mathrm{~m}$ ). The dominant species in the neritic group is Paralia sulcata (Table 3), sometimes considered an indicator of shallow, moving water (Sancetta, 1982). Neritic species are lowest during the Termination V Laminations and increase dramatically around $404 \mathrm{ka}$ (124.61 m b.s.f.) to almost $50 \%$ of the assemblage (Fig. $7 \mathrm{n}$ ). $L$. cf. ocellata is the dominant taxa in the freshwater group. This group is notably absent from much of the core but prevalent between 401 and $392 \mathrm{ka}(123.70 \mathrm{mb}$ b.s.f. and $121.20 \mathrm{~m}$ b.s.f.); it reaches its highest relative percent abundance (12\%) at $401 \mathrm{ka}(123.62 \mathrm{~m}$ b.s.f.) (Fig. $7 \mathrm{n})$.

Neodenticula seminae is used here as a tracer of Pacific water (Caissie et al., 2010; Katsuki and Takahashi, 


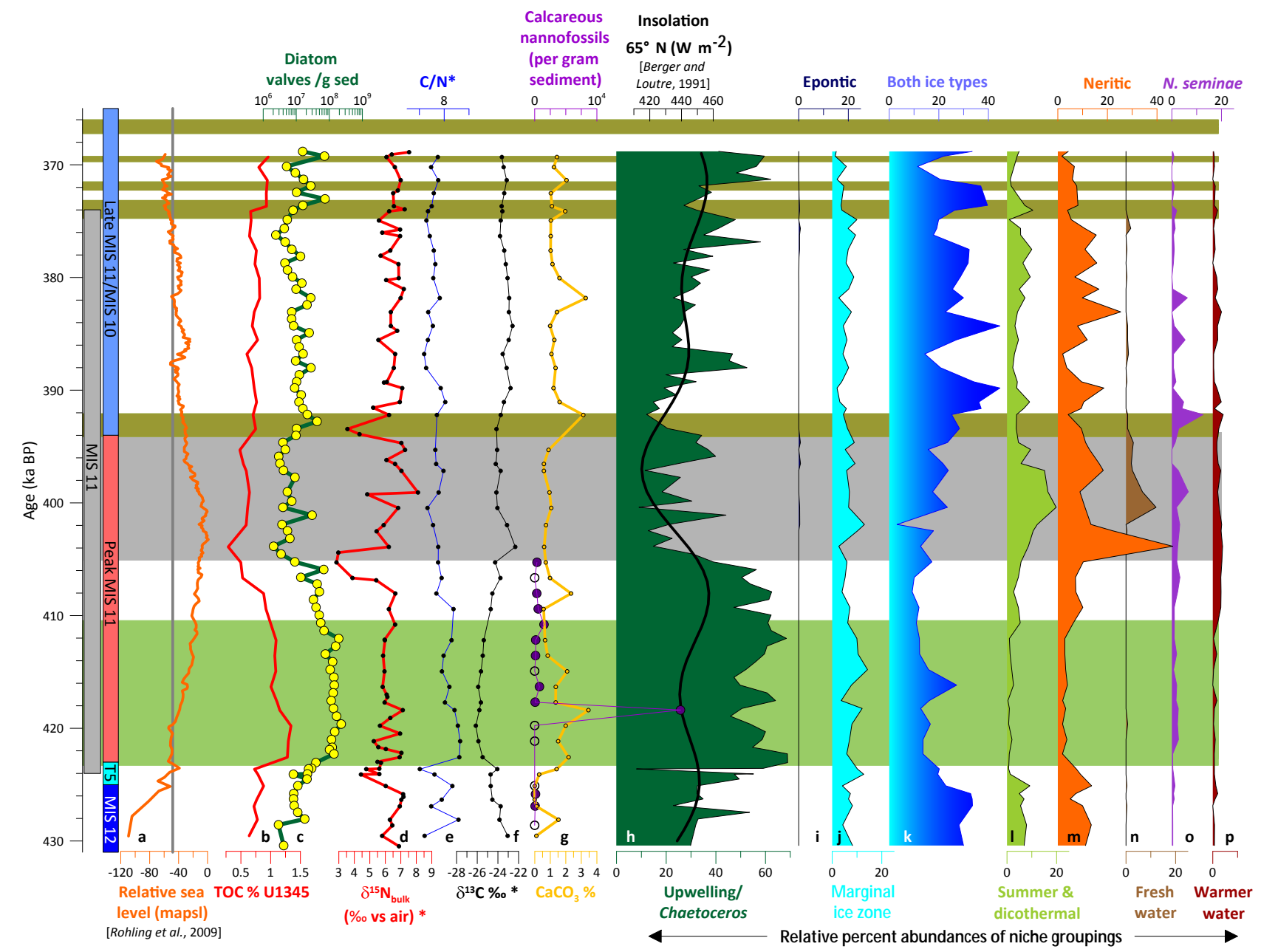

Figure 7. Summary of geochemistry and biological proxies. The grey vertical bar depicts the duration of MIS 11 and colored vertical bars refer to the zones mentioned in the text. (a) Global eustatic sea level (orange) is plotted for reference (Rohling et al., 2010). The sill depth of Bering Strait ( -50 ma.p.s.l.) is shown as a vertical grey line. Total organic carbon (b, red) is plotted with the total diatom abundance (c, green line, yellow dots). Geochemical data are plotted as $\delta^{15} \mathrm{~N}\left(\mathbf{d}\right.$, red), $\mathrm{C} / \mathrm{N}$ (e, blue), $\delta^{13} \mathrm{C}$ (f, black), and \%CaCO 3 (g, yellow). Biological proxies include absolute abundance of calcareous nannofossils (g, purple). Open circles indicate barren samples; closed circles indicate samples that had calcareous nannofossils present. Relative percent abundances of diatoms are grouped by environmental niche. Chaetoceros RS are green (h), epontic species are navy blue (i), marginal ice zone species are light blue (j), species that fall under both ice categories are shaded with a gradational blue (k), summer and dicothermal species are light green (l), neritic species are orange (m), freshwater species are brown (n), N. seminae is purple (o), and warmer water species are maroon (p). Insolation at $65^{\circ} \mathrm{N}$ (black) is overlain on Chaetoceros RS relative percent abundances. Type I laminations are depicted as pale-green bars and type II laminations are depicted as olive-green bars. A grey bar indicates the anomalous interval.

2005). Absolute abundances begin to increase at $422 \mathrm{ka}$ as global eustatic sea level rises above $-50 \mathrm{~m}$ a.p.s.l. Abundance then decreases slowly over the course of the Termination V Laminations and peaks again at 392 and $382 \mathrm{ka}$. As sea level drops below $-50 \mathrm{~m}$ a.p.s.l., $N$. seminae is no longer present at U1345. Relative percent abundances remain stable at $\sim 2 \%$ relative percent abundance between 422 and $400 \mathrm{ka}(129.62-123.62 \mathrm{~m}$ b.s.f.) and then peak at $13 \%$ at $392 \mathrm{ka}$ (121.22 m b.s.f.) (Figs. 6 and 7o).

Diatoms associated with warmer water or classified as members of temperate to subtropical assemblages (Table 3) are quite low throughout the record $(<5 \%)$, and are highest (3-4\%) during mid- to late MIS 11 at approximately $\sim 410$ to $391 \mathrm{ka}(126.74-116.50 \mathrm{~m}$ b.s.f.) (Fig. 7p).

\subsection{Calcareous nannofossils}

Calcareous nannofossils were examined between 432 and $405 \mathrm{ka}$ (133.4-125.0 $\mathrm{m}$ b.s.f.); one-third of the samples were barren (Fig. 7g, open purple circles) and only one sample (418 ka; $128.8 \mathrm{~m}$ b.s.f.) had sufficient individuals to estimate relative percent abundances (Fig. 7g). This sample is located 
midway through the Termination V Laminations when the diatom assemblage is overwhelmingly dominated by Chaetoceros RS. Small Gephyrocapsa dominates $(>50 \%)$ the calcareous nannofossil assemblage. There are $35 \%$ medium Gephyrocapsa, $9 \%$ Coccolithus pelagicus, and $1 \%$ Gephyrocapsa oceanica.

\subsection{Geochemistry}

\subsubsection{Organic and inorganic carbon content}

Total organic carbon (TOC) roughly follows the trend of relative percent abundances of Chaetoceros RS, with higher values during the Termination V Laminations (Fig. 7b, 7h). The mean TOC value during MIS 12 is $0.76 \%$, and during the Termination V Laminations it is $1.11 \%$. TOC decreases between 408 (125.82 m b.s.f.) and $404 \mathrm{ka}$ (124.77 m b.s.f.), coeval with a decrease in $\delta^{15} \mathrm{~N}$ values. After $404 \mathrm{ka}$, it increases linearly to $374 \mathrm{ka}(115.39 \mathrm{~m}$ b.s.f.). TOC is again high during the late MIS 11/MIS 10 laminations.

In contrast, inorganic carbon, calculated as $\% \mathrm{CaCO}_{3}$, is less than $1 \%$ for most of the record (Fig. $7 \mathrm{~g}$ ). However, it increases up to $3.5 \%$ during the laminated intervals and also at $382 \mathrm{ka}$ (117.87 m b.s.f.), $392 \mathrm{ka}$ (110.00 m b.s.f.), and $408 \mathrm{ka}$ (125.82 m b.s.f.).

\subsubsection{Terrigenous vs. marine input indicators}

Nitrogen, carbon, and their isotopes can be used to determine relative amounts of terrigenous vs. marine organic mater input. Total nitrogen (TN) is significantly correlated with total organic carbon (TOC) (Fig. 8a); however, the $y$ intercept of a regression line through the data is 0.03 (Fig. 8a), indicating that there is a significant fraction of inorganic nitrogen in the sediments (Schubert and Calvert, 2001). Inorganic nitrogen can be adsorbed onto clay particles or incorporated into the crystal lattice of potassium-rich clays such as illite. This complicates interpretations of elemental nitrogen and its isotopes because the presence of inorganic nitrogen will lower $\mathrm{C}_{\text {org }} / \mathrm{N}$ ratios and $\delta^{15} \mathrm{~N}$ values (Muller, 1977; Schubert and Calvert, 2001).

Bearing this bias in mind, the relative terrigenous contribution to the sediments can be estimated by examining where U1345 samples plot in relation to typical $\mathrm{C}_{\text {org }} / \mathrm{N}, \delta^{15} \mathrm{~N}$, and $\delta^{13} \mathrm{C}$ values for marine phytoplankton, refractory soil organic matter, and $\mathrm{C} 3$ vascular plants (Fig. 8). Note that we use $\mathrm{N} / \mathrm{C}_{\text {org }}$, the inverse of $\mathrm{C}_{\text {org }} / \mathrm{N}$, because we seek to derive the terrigenous carbon fraction rather than the fraction of terrigenous nitrogen (Perdue and Koprivnjak, 2007). Throughout MIS 12-10, organic matter is comprised of a mixture of marine and terrigenous organic matter. There is a higher contribution of marine organic matter during MIS 12, 10, and between 394 and $405 \mathrm{ka}$, as well as a higher contribution of terrigenous organic matter during peak MIS 11 (Fig. 8). The $\mathrm{N} / \mathrm{C}_{\text {org }}$ ratio indicates that, during peak MIS 11, this terrige- nous organic matter is likely refractory soil organic matter, rather than fresh vascular plant organic matter (Fig. 8b).

During MIS $12, \mathrm{C}_{\text {org }} / \mathrm{N}$ is highly variable, when sea level is below $-50 \mathrm{~m}$ a.p.s.l. (Fig. 7). As sea level rises during Termination $\mathrm{V}, \mathrm{C}_{\mathrm{org}} / \mathrm{N}$ values increase from 6 to more than 9 . The highest $\mathrm{C}_{\text {org }} / \mathrm{N}$ value occurs at the start of the Termination V Laminations. $\mathrm{C}_{\text {org }} / \mathrm{N}$ decreases as sea level rises until at $400 \mathrm{ka}(123.62 \mathrm{~m}$ b.s.f.) it stabilizes near 7 for the remainder of the record (Fig. 7).

Carbon isotopic values range between -22 and $-26 \%$. No sample has high enough $\delta^{13} \mathrm{C}$ values to be comprised fully of typical Arctic Ocean marine phytoplankton (-22 to $-19 \%$ ) or ice-related plankton $(-18.3 \%$ ) (Schubert and Calvert, 2001); however, samples from MIS 10, MIS 12, and the "anomalous interval" all plot close to marine phytoplankton values (Fig. 8b). At the onset of the Termination V Laminations, $\delta^{13} \mathrm{C}$ becomes more negative and then gradually increases to a maximum of -22.33 at $404 \mathrm{ka}$ (124.62). After $400 \mathrm{ka}\left(123.5 \mathrm{~m}\right.$ b.s.f.), $\delta^{13} \mathrm{C}$ is relatively stable around $-23.5 \%$ (Fig. 7 ).

\subsubsection{Nitrogen isotopes}

The nitrogen isotopic composition of bulk marine sediments can be thought of as a combination of the $\delta^{15} \mathrm{~N}$ of the source nitrate and the amount of nitrogen utilization by phytoplankton (Brunelle et al., 2007). Denitrification is common in the low-oxygen waters of the eastern tropical North Pacific (Liu et al., 2005) and in the Bering Sea during the Bølling-Allerød (Schlung et al., 2013), leading to enriched core-top $\delta^{15} \mathrm{~N}$ values between 8 and $9 \%$. When diatoms utilize nitrogen, they preferentially assimilate the lighter isotope, ${ }^{14} \mathrm{~N}$, which enriches surface waters with respect to ${ }^{15} \mathrm{~N}$ (Sigman et al., 1999). Complete nitrogen utilization would result in $\delta^{15} \mathrm{~N}$ values identical to that of the source nitrate (Sigman et al., 1999). Sponge spicules (very low $\delta^{15} \mathrm{~N}$ values) and radiolarians (highly variable $\delta^{15} \mathrm{~N}$ values) may contaminate the $\delta^{15} \mathrm{~N}$ of bulk organic matter; therefore, we looked for and found no correlation between spicule abundance and $\delta^{15} \mathrm{~N}$ in our samples.

$\delta^{15} \mathrm{~N}$ is relatively stable but quite high throughout the study interval, fluctuating around an average value of $6.4 \%$ and reaching values greater than $7 \%$ and up to $8 \%$ several times (Fig. 7). There are several notable excursions from these high values. Coeval with sea level rise and increased relative percent Chaetoceros RS, $\delta^{15} \mathrm{~N}$ decreased 2.7 to $4.4 \%$ o before recovering to average values during the Termination V Laminations. Two other depletions occur at $405 \mathrm{ka}$ (124.77 m b.s.f.) and $393 \mathrm{ka}(121.62 \mathrm{~m}$ b.s.f.), the first of which is the most extreme and reaches $2.9 \%$. 

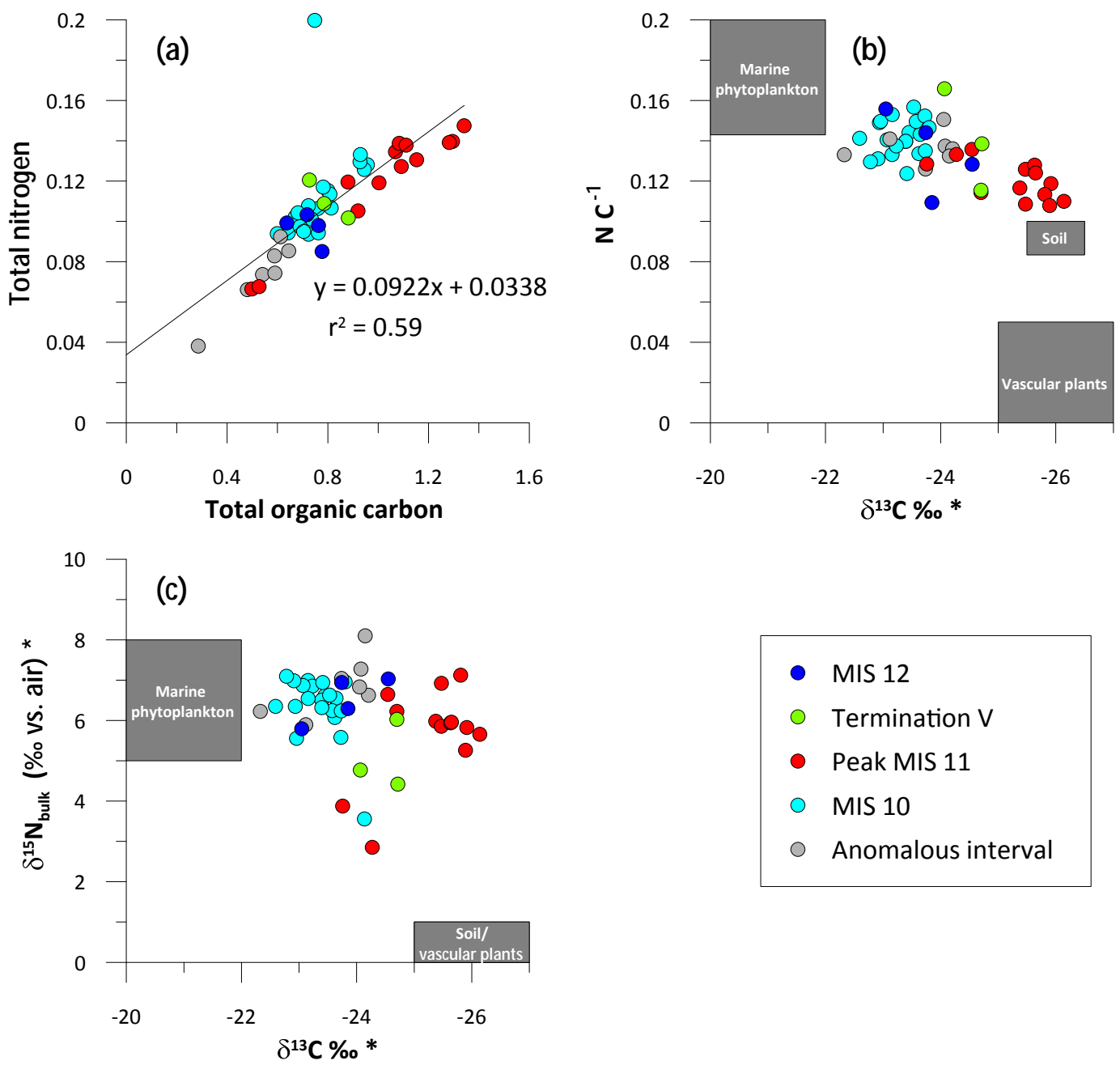

Figure 8. Cross plots of (a) total nitrogen vs. total organic carbon, (b) $\mathrm{N} / \mathrm{C}_{\text {org }}$ vs. $\delta^{13} \mathrm{C}$, and (c) $\delta^{15} \mathrm{~N}$ vs. $\delta^{13} \mathrm{C}$. For each panel, the range of composition of each organic matter source is plotted in a grey box: marine phytoplankton (C / N: 5-7 - Redfield, 1963; Meyers, 1994; $\delta^{13} \mathrm{C}:-19$ to $-22 \%$ - Schubert and Calvert, $2001 ; \delta^{15} \mathrm{~N}$ : 5 to $8 \%$ - Walinsky et al., 2009); Soil (C / N: $10-12, \delta^{13} \mathrm{C}:-25.5$ to $-26.5 \%$, $\delta^{15} \mathrm{~N}$ : 0 to $1 \%$ - Walinsky et al., 2009); C3 vascular plants (C / N: $>20$ - Redfield, 1963; Meyers, 1994; $\delta^{13} \mathrm{C}:-25$ to $-27 \%$ - Schubert and Calvert, $2001 ; \delta^{15} \mathrm{~N}$ : 0 to $1 \%$ - Walinsky et al., 2009).

\section{Discussion}

\subsection{Orbital-scale changes in productivity and sea ice}

The observed changes in diatom assemblages and lithology (Fig. 7) allow us to break the sedimentary record into five zones: MIS 12, Termination V, peak MIS 11, anomalous interval, and late MIS 11 (Table 2). These zones reflect changing sea ice, glacial ice, sea level, and sea surface temperature (SST) and correspond to events recognized elsewhere in ice cores and marine and lake sediments.

\subsubsection{Marine Isotope Stage 12 and early deglaciation (431-425 ka)}

From 431 to $425 \mathrm{ka}$, the record chronicles conditions at the end of MIS 12. Although diatom accumulation rate is quite low, a relatively diverse assemblage characterizes this period (Fig. 5) with moderate amounts of sea ice, high productivity, and dicothermal species (Fig. 7), indicating seasonal sea ice with highly stratified waters during the ice-melt season. Nitrogen isotopes indicate high nutrient utilization (Fig. 7) consistent with nitrogen-limited productivity in stratified waters as well as localized denitrification. Numerous shell fragments, two sand layers, and the highest percentages of clay-sized sediments in the record were deposited during MIS 12 (Figs. 4 and 8), indicating input of terrigenous material; however, cross plots of elemental $\left(\mathrm{C}_{\text {org }} / \mathrm{N}\right.$ or 
$\left.\mathrm{N} / \mathrm{C}_{\text {org }}\right)$ and isotopic $\left(\delta^{13} \mathrm{C}, \delta^{15} \mathrm{~N}\right)$ indicators of terrigenous and marine carbon pools indicate that the organic matter during MIS 12 is a diverse mix of marine phytoplankton and soil detritus (Fig. 8) likely derived from in situ, but low, productivity and transport by several methods including large, oligotrophic rivers and downslope transport. Glacial ice was likely restricted to mountain-valley glaciers, similar to the Last Glacial Maximum (e.g., Glushkova, 2001). These small, distant glaciers would not have produced large amounts of icebergs though occasional glacial IRD may have come from the Koryak Mountains, the Aleutians, or Beringia. Consistent with this, sediments typical of glacial IRD, such as dropstones, are sparse but present. In addition, sea ice rafting tends to preferentially entrain clay and silt (Reimnitz et al., 1998) and is likely to be an important contributor of terrigenous sediments.

\subsubsection{Termination V (425-423 ka)}

Termination $\mathrm{V}$ is the transition from MIS 12 to MIS 11 . Worldwide, it is a rapid deglaciation that is followed by a long (up to $30 \mathrm{kyr}$ ) climate optimum (Milker et al., 2013). At U1345, gradually increasing productivity coupled with decreasing nutrient utilization and sea ice occurs between 425 and $423 \mathrm{ka}$. This is seen as an increase in absolute diatom abundances and relative percent abundance of Chaetoceros RS and a decrease in sea ice diatoms and $\delta^{15} \mathrm{~N}$ values (Fig. 7). It is plausible that increased nitrogen availability drove higher primary productivity as floods scoured fresh organic matter from the submerging continental shelf (Bertrand et al., 2000). Rapid input of bioavailable nitrogen as the shelf was inundated has been suggested to explain increasing productivity during the last deglaciation in the Sea of Okhotsk (Shiga and Koizumi, 2000) and during MIS 11 in the North Atlantic (Poli et al., 2010) and also may have contributed to dysoxia by ramping up nutrient recycling, bacterial respiration, and decomposition of organic matter in the Bering Sea.

\subsubsection{Peak MIS 11 (423-394ka)}

Globally, peak interglacial conditions (often referred to as MIS 11.3 or $11 \mathrm{c}$ ) are centered around 400 to $410 \mathrm{ka}$ (Dutton et al., 2015; Raymo and Mitrovica, 2012), though the exact interval of the temperature optimum varies globally and lasted anywhere from 10 to $30 \mathrm{kyr}$ (Kandiano et al., 2012; Kariya et al., 2010; Milker et al., 2013). At U1345, peak interglacial conditions begin during the Termination V Laminations at $423 \mathrm{ka}$ and continue until $394 \mathrm{ka}$, lasting nearly $30 \mathrm{kyr}$, consistent with the synthesis of the PAGES Past Interglacials Working Group (2016).

\section{Laminations (423-410 ka)}

A $3.5 \mathrm{~m}$ thick laminated interval is deposited during early MIS 11, beginning at $423 \mathrm{ka}$ (Fig. 7), when insolation was high at $65^{\circ} \mathrm{N}$ (Berger and Loutre, 1991). Its presence indicates that the bottom water at $1000 \mathrm{~m}$ in the Bering Sea was dysoxic for more than $12 \mathrm{kyr}$. These laminations are characterized as type I laminations with a high diatom content (Fig. 4). Several lines of evidence point towards high productivity among multiple phytoplankton groups as opposed to simply a change in preservation. First, we see an increase in diatom abundances by 2 orders of magnitude increase since MIS 12; second, a low-diversity diatom assemblage dominated by Chaetoceros RS; third, an abrupt increase in percent organic carbon; and fourth, high percent $\mathrm{CaCO}_{3}$ and abundant calcareous nannofossils dominated by small Gephyrocapsa. Furthermore, enriched $\delta^{15} \mathrm{~N}$ values indicate either increased nitrogen utilization that likely led to this increased productivity or localized denitrification in low-oxygen waters (Fig. 7).

Sea ice extent decreases during this interval, with no epontic diatoms present and reduced amounts of sea ice diatoms found in both epontic and marginal ice (Fig. 7). Geochemical cross plots indicate a high contribution from soil detritus and C3 plant organic matter (Fig. 8). At the onset of the laminated interval (423 ka), $\delta^{13} \mathrm{C}$ decreases and $\mathrm{C}_{\text {org }} / \mathrm{N}$ increases rapidly (Fig. 7) as the tundra-covered Bering Sea shelf is flooded.

However, the diatom record during the laminated interval has the lowest contribution of neritic diatoms and virtually no freshwater diatoms (Fig. 7), suggesting that although terrigenous organic matter was an important input at the site, coastal, river, or swamp/tundra diatoms were not carried out to U1345 with this terrigenous organic matter.

\section{Post-laminations (410-394 ka)}

Both high $\mathrm{N} / \mathrm{C}_{\text {org }}$ and $\delta^{13} \mathrm{C}$ indicate that input of terrigenous organic matter is highest at the onset of the Termination $\mathrm{V}$ Laminations and then declines until mid-MIS 11 (400 ka), at which time the organic matter is largely derived from marine phytoplankton (Fig. 7; red to grey dots in Fig. 8). This may be related to rising eustatic sea level causing the migration of the paleoshoreline farther northward and away from U1345.

Throughout MIS 11, Chaetoceros RS, a species indicative of high productivity, is generally higher when insolation is higher and lower when isolation is lower (404$390 \mathrm{ka}$; Fig. 7). However, although their fluctuations are small, warm-water species show the opposite trend, with higher proportions of warm-water diatoms when insolation is low (Fig. 7). If higher proportions of warm-water diatoms indicate warmer water, then this suggests that productivity is highest in colder waters when insolation is high, and lowest in warmer waters when insolation is low. This may reveal a relationship between upwelling of colder waters and high productivity. 


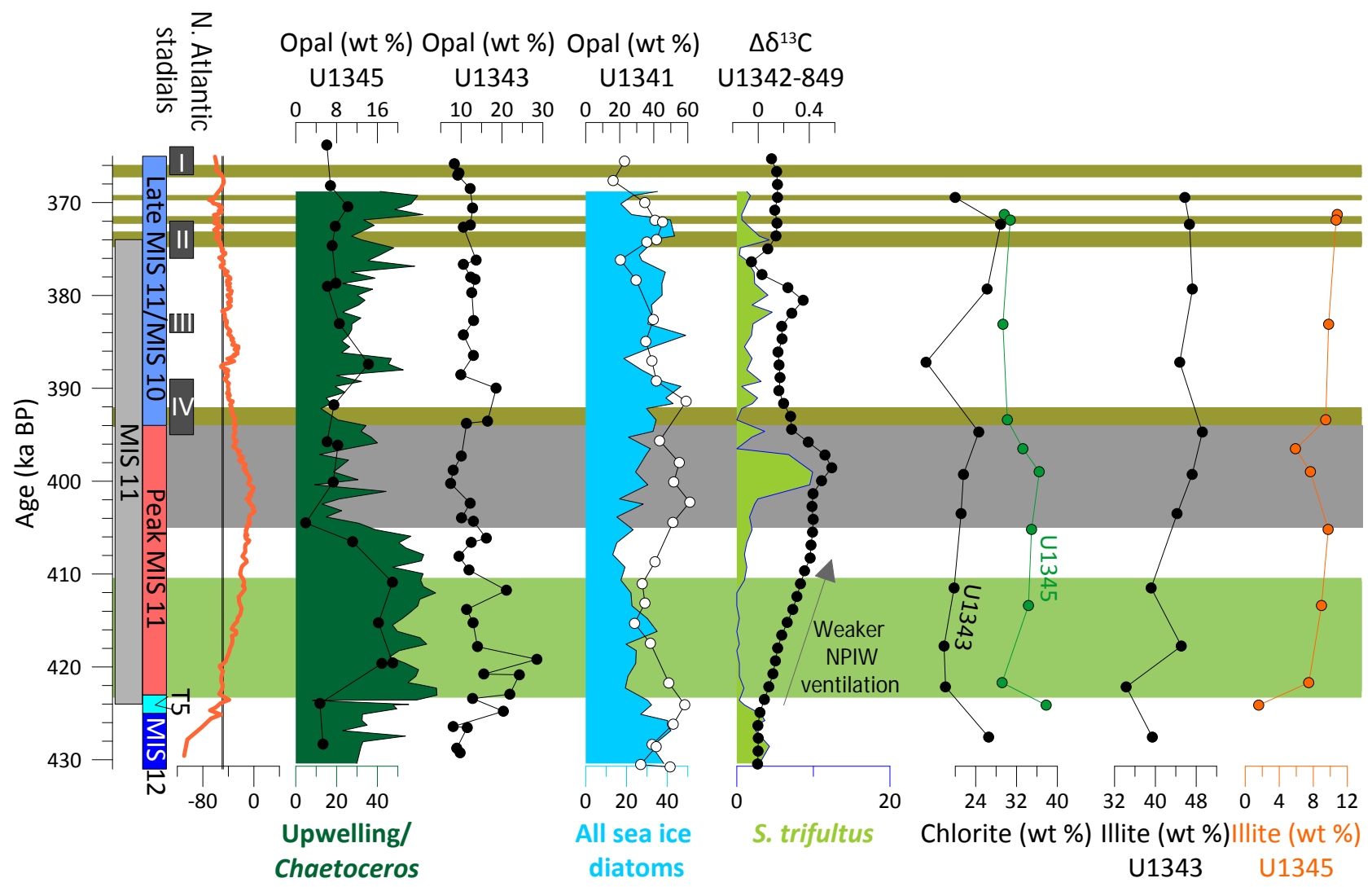

Figure 9. Comparison of Site U1345 with other Bering Sea (U1340, U1341, U1343) and global sites. The grey vertical bar depicts the duration of MIS 11, colored vertical bars refer to the zones mentioned in the text, and dark-grey bars show the timing of North Atlantic stadials (I-IV) (Voelker et al., 2010). Global eustatic sea level (orange) is plotted for reference (Rohling et al., 2010). The sill depth of Bering Strait (-50 m a.p.s.1.) is shown as a vertical grey line. Weight \% opal from sites U1345, U1343, and U1341 (Kanematsu et al., 2013) is plotted with Chaetoceros RS relative percent abundances, and relative percent abundances of all sea ice diatoms. The difference in benthic foraminiferal $\delta^{13} \mathrm{C}$ between the Bowers Ridge (U1342) and the North Pacific (ODP 849), a proxy for North Pacific Intermediate Water ventilation, is plotted with relative percent abundances of Shionodiscus trifultus, an indicator of highly stratified water. Note that ventilation increases to the left. The weight percent of the clay minerals, chlorite, and illite are plotted for sites U1343 (Kim et al., 2015 ) and U1345 (this study). Type I laminations are depicted as pale-green bars and type II laminations are depicted as olive-green bars. A grey bar indicates the "anomalous interval".

\subsubsection{Late MIS 11 to MIS 10 (younger than $394 \mathrm{ka}$ )}

After $394 \mathrm{ka}$, diatom productivity indicators are the lowest in the record but linearly increase to the top of the record. This is in contrast to a slight increase in diatom abundance, which increases at $393 \mathrm{ka}$ and then remains relatively stable into MIS 10. Sea ice indicators also remain relatively high from 392 to the top of the record and dicothermal species reflect moderately stratified waters. Warm water species decrease from $390 \mathrm{ka}$ to the top of the record (Fig. 7). The sum of this evidence indicates that, at the end of MIS 11, summers were warm and sea ice occurred seasonally, perhaps lasting a bit longer than at other times in the record.

Eustatic sea level decreased beginning about $402 \mathrm{ka}$ (Rohling et al., 2010), but sea level remained high enough to allow $N$. seminae to reach the shelf slope break until about 380 ka (Fig. 7).

\subsection{The Bering Sea in the context of regional and global variability}

Across the Bering Sea, sediments at sites near Bowers Ridge (Fig. 1) are dominated by opal during MIS 11 (Kanematsu et al., 2013); however, biogenic sediments at sites along the Bering Slope, including U1345, are diluted by sea ice transport of lithogenic sediments as well as down-slope sediment transport (Kanematsu et al., 2013). However, the rate of biogenic opal accumulation is comparable for all sites in the Bering Sea, despite differences in sedimentation rates (Kanematsu et al., 2013; Stroynowski et al., 2015). Opal content in the sediments varies on glacial-interglacial timescales with high productivity during interglacials. Indeed, the highest percent opal concentration of the past $1 \mathrm{Ma}$ occurs during MIS 11 at the two slope sites, U1345 and U1343 (Kanematsu et al., 2013). 
Biogenic opal increases during early MIS 11 at sites U1343 and U1345 (Kanematsu et al., 2013). At U1345, it mimics the pattern of relative percent abundance of Chaetoceros RS, the most abundant productivity indicator (Fig. 9). Although diatom data from other cored sites are low resolution (1-4 samples during MIS 11) (Kato et al., 2016; Onodera et al., 2016; Stroynowski et al., 2015; Teraishi et al., 2016), they provide a snapshot of diatom assemblages during MIS 11. Sea ice diatoms contribute approximately $30 \%$ of the diatom assemblages at the two slope sites, U1345 (this study) and U1343 (Teraishi et al., 2016), and between 10 and $20 \%$ of the assemblage at the eastern Bowers Ridge site (U1340) (Stroynowski et al., 2015), but less than $2 \%$ of the assemblage on the western flanks of Bowers Ridge (U1341) (Onodera et al., 2016). In the North Pacific (ODP Site 884), no sea ice diatoms are present during MIS 11 (Kato et al., 2016). Site U1341 contained an assemblage high in dicothermal indicators such as Shionodiscus trifultus and Actinocyclus curvatulus, oceanic front indicators such as Rhizosolenia hebetata, and N. seminae (Onodera et al., 2016), while the North Pacific (Site 884) assemblage is dominated by dicothermal indicators during MIS 11 (Kato et al., 2016). Percent opal declines at Bowers Ridge during early MIS 11 at the same time as it increases at the slope sites (Iwasaki et al., 2016) (Fig. 9) when sea ice is reduced and upwelling along the shelf-slope break is increased. This implies that the relationship between productivity and sea ice in the Bering Sea is perhaps more complex than the simple idea that sea ice inhibits productivity (Iwasaki et al., 2016; Kim et al., 2016). The region is strongly influenced by winter sea ice throughout MIS 11, with seasonal sea ice present farther south along the slope than today and also in the eastern Bering Sea. Highly stratified waters, perhaps due to the seasonal expansion and retreat of sea ice, extended across the entire basin and even into the North Pacific.

Local ventilation of North Pacific Intermediate Water decreased as the Bering Strait opened during Termination V with the weakest ventilation occurring around $400 \mathrm{ka}$ (Knudson and Ravelo, 2015). This is coeval with the highest relative percent abundances of dicothermal diatoms, indicating highly stratified water (Fig. 9).

\subsubsection{Temperature and aridity during MIS 11}

When sea level was low during glacial periods such as MIS 12 (Rohling et al., 2010), U1345 was proximal to the Beringian coast (Fig. 2). With the Bering land bridge exposed, the continent was relatively cold and arid (Glushkova, 2001). In western Beringia, Lake El'gygytgyn was perennially covered with ice, summer air temperatures were warming in sync with increasing insolation from 4 to $12^{\circ} \mathrm{C}$, but annual precipitation was low $(200-400 \mathrm{~mm})$ (Vogel et al., 2013).

As sea level rose, and global ice volume reached the lowest amount for the past $500 \mathrm{kyr}$ (Lisiecki and Raymo,
2005), the generally continental temperatures in the Northern Hemisphere increased (D'Anjou et al., 2013; de Vernal and Hillaire-Marcel, 2008; Lozhkin and Anderson, 2013; Lyle et al., 2001; Melles et al., 2012; Pol, 2011; Prokopenko et al., 2010; Raynaud et al., 2005; Tarasov et al., 2011; Tzedakis, 2010; Vogel et al., 2013), with a northward expansion of boreal forests in Beringia (Kleinen et al., 2014). However, the marine realm does not reflect this warming as strongly. At U1345, the relative percent of warm-water species suggests that SSTs during peak MIS 11 were only slightly warmer than during MIS 12. Indeed, MIS 11 is not the warmest interglacial in most marine records (Candy et al., 2014); rather, MIS 5e is the warmest in many places (PAGES Past Interglacials Working Group, 2016). This is especially evident in the Nordic Seas, where MIS 11 SSTs were lower than Holocene values (Bauch et al., 2000). However, MIS 11 is unique because it was much longer than MIS 5e in all records (PAGES Past Interglacials Working Group, 2016). One exception to this is the Arctic Ocean, which was warm enough during MIS 11 to imply increased Pacific water input through Bering Strait (Cronin et al., 2013).

With elevated sea level, peak MIS 11c was very humid in many places. In the Bering Sea, modeling studies estimate up to $50 \mathrm{~mm}$ more precipitation than today at $410 \mathrm{ka}$ (Kleinen et al., 2014). The most humid, least continental period recorded in the sediments at Lake Baikal occurs from 420 to $405 \mathrm{ka}$ (Prokopenko et al., 2010), and extremely high precipitation is recorded at Lake El'gygytgyn on the nearby Chukotka Peninsula from 420 to $400 \mathrm{ka}$ (Melles et al., 2012).

\subsubsection{Millennial-scale laminations and changes in sea ice}

Globally, late MIS 11 is characterized as a series of warm and cold cycles (Candy et al., 2014; Voelker et al., 2010), though there is no agreement on the timing of these cycles. At Site U1345, laminations are deposited intermittently between 394 and $392 \mathrm{ka}$ and again after $375 \mathrm{ka}$ (Fig. 4) as the climate transitioned into MIS 10. These laminations are quite different from the Termination V Laminations due to their shorter duration and lack of obvious shift in terrigenous vs. marine carbon source. In addition, these type II laminations have higher diatom abundances and $\mathrm{CaCO}_{3}$, but lack increased upwelling indicators. Primary production during these laminations is likely not driven by nutrient upwelling along the shelf-slope break. Instead, most of these laminations show an increase in sea ice diatoms and roughly correspond to millennial-scale stadial events that occurred during late MIS 11 in the North Atlantic (Fig. 9) (Voelker et al., 2010) as well as carbonate peaks at Blake Ridge (Chaisson et al., 2002). This suggests teleconnections between the Bering Sea and the North Atlantic at this time and places an indirect constraint on the depth of the Bering Strait sill.

It is possible to note that the laminations occur at a time when global sea level was fluctuating near the sill depth of 


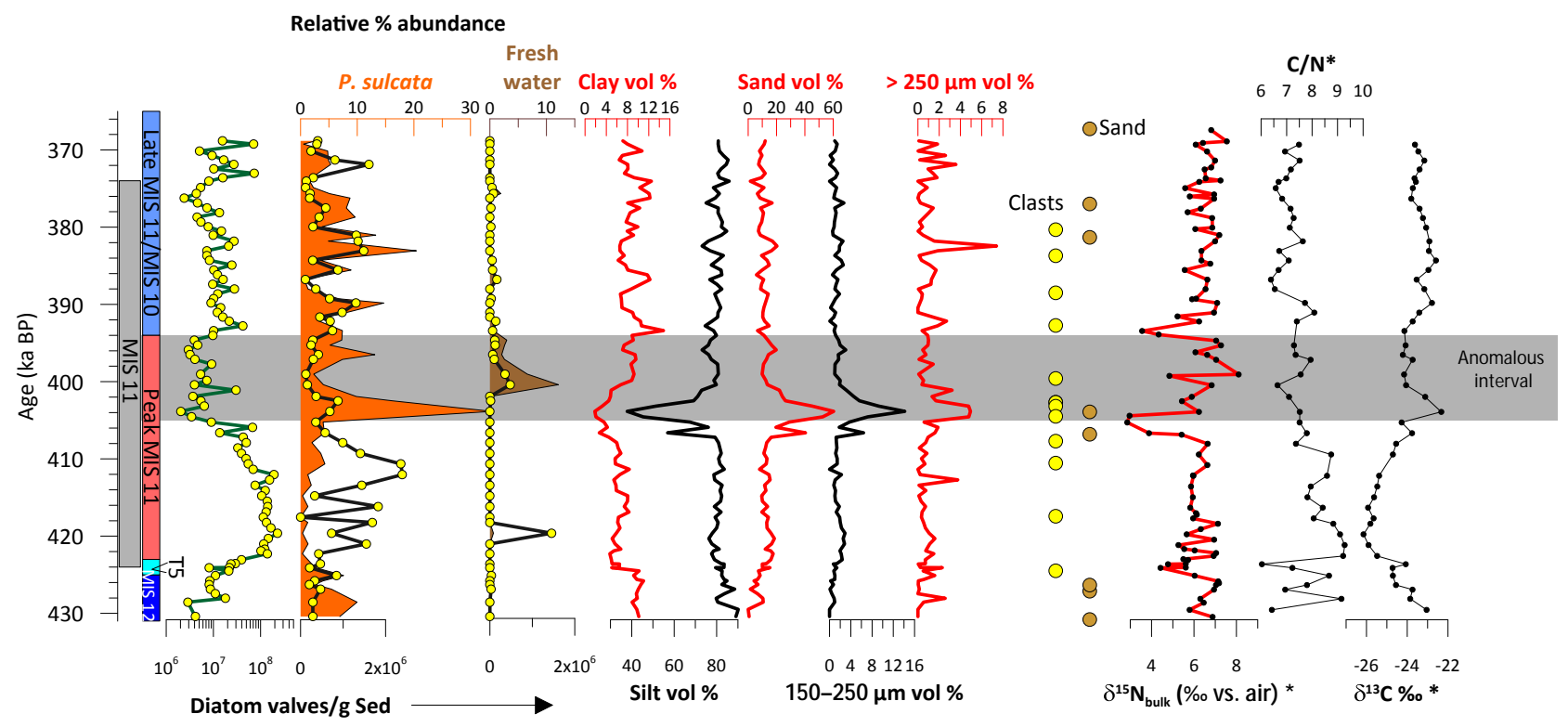

Figure 10. Proxy indicators of shelf to basin transport. The grey vertical bar depicts the duration of MIS 11; colored vertical bars refer to the zones mentioned in the text. Total diatom absolute abundances are plotted next to absolute (line plots) and relative percent abundance of $P$. sulcata (orange area plot) and freshwater species (brown area plot). High-resolution grain size includes \% clay (red), silt (black), sand (red), 150-250 $\mu \mathrm{m}$ (black) and greater than $250 \mu \mathrm{m}$ (red). Yellow circles indicate isolated clasts (IRD), maroon circles indicate sand layers for all holes at U1345. Geochemical data are plotted as $\delta^{15} \mathrm{~N}$ (red), C / N (black), and $\delta^{13} \mathrm{C}$ (black). The grey bar spans $405-394 \mathrm{ka}$, the so-called "anomalous interval".

Bering Strait ( $-50 \mathrm{~m}$ a.p.s.l.) (Rohling et al., 2010) (see grey line at $-50 \mathrm{~m}$ in Fig. 9). When sea level fluctuates near this level, Bering Strait modulates widespread climate changes that see-saw between the Atlantic and Pacific regions on millennial-scale time frames (Hu et al., 2010). Moreover, when Bering Strait is closed, North Pacific Intermediate Water formation increases (Knudson and Ravelo, 2015). Further study will elucidate these connections.

A "Younger Dryas-like" temperature reversal is seen midway through Termination $\mathrm{V}$ in the North Atlantic (Voelker et al., 2010), in Antarctica (EPICA Community Members, 2004), and at Lake El'gygytgyn (Vogel et al., 2013); however, there is no evidence for such an event in the Bering Sea.

\subsubsection{Anomalous interval (405-394 ka)}

The interval between 405 and $394 \mathrm{ka}$ contains a number of unusual characteristics. Diatom assemblages are similar to those found in nearshore sediments from the Anvillian Transgression $800 \mathrm{~km}$ northeast of U1345 in Kotzebue Sound (Fig. 1) (Pushkar et al., 1999). A large peak in neritic species occurs at $404 \mathrm{ka}$ followed by the highest relative percentages of freshwater species at the site and a slight increase in sea ice diatoms from 400 to $394 \mathrm{ka}$ (Fig. 7, grey bar). Primary productivity was low during this interval with the highest $\delta^{15} \mathrm{~N}$ values of MIS 11, likely indicating denitrification. However, two large depletions in $\delta^{15} \mathrm{~N}$ bracket this interval and occur as Chaetoceros RS decrease in relative percent abundance (Fig. 10). The organic matter is primarily sourced from marine phytoplankton, similar to the organic matter found during the two glacial intervals and distinctly different from the organic matter found during the rest of peak MIS 11 (Fig. 8). Detailed grain size analysis shows a fining-upward trend of clay-sized grains as well as a broad increase in sand sized grains and in particular grains greater than $250 \mu \mathrm{m}$ (Fig. 10). All samples are poorly to very poorly sorted (see Supplement). Shipboard data show an increase in the presence of pebbles, several sand layers (Fig. 10), and a thick interval of silty sand (Takahashi et al., 2011) at $404 \mathrm{ka}$ (Fig. 4). While the presence of coarse material implies a terrestrial source for the sediments during this interval, this terrestrial matter must have been largely devoid of organic matter. The sum of this evidence leads us to further investigate three different interpretations of the interval highlighted in grey in Fig. 10: a reversal of flow through Bering Strait, a tidewater glacial advance, and a turbidite.

\section{Reversal of Bering Strait throughflow}

As sea level rose after MIS 12, the connection between the Pacific and the Atlantic was reestablished via Bering Strait. De Boer and Nof (2004) suggest that under high sea level conditions, if freshwater is suddenly released into the North Atlantic, the Bering Strait might act as an "exhaust valve" allowing freshwater from the Arctic Basin and the North 
Atlantic to flow into the Arctic Ocean and then flow south through the Bering Strait, thus preventing a shut-down in thermohaline circulation (DeBoer and Nof, 2004).

On St. Lawrence Island (Fig. 1), evidence for Arctic mollusks entering the Gulf of Anadyr suggests that flow through Bering Strait was reversed at some point during the Middle Pleistocene (Hopkins, 1972). Unfortunately, this event is poorly dated.

If flow were reversed due to a meltwater event (DeBoer and Nof, 2004), we would expect a temporary reduction in North Atlantic Deep Water (NADW) formation and an increase in southerly winds from Antarctica (DeBoer and Nof, 2004). In the Bering Sea, we would expect to see an increase in common Arctic or Bering Strait diatom species and a decrease in North Pacific indicators. In addition, the clay minerals in the Arctic Ocean are overwhelmingly dominated by illite (Ortiz et al., 2012), which tends to adsorb large amounts of ammonium (Schubert and Calvert, 2001). Thus, if net flow were to the south, one might expect to find increased illite and decreased $\mathrm{C}_{\text {org }} / \mathrm{N}$ and $\delta^{15} \mathrm{~N}$ values.

Proxy evidence for NADW ventilation indicates that, between 412 and $392 \mathrm{ka}$, NADW formation decreased for short periods ( $<1 \mathrm{ka}$ ) (Poli et al., 2010). In contrast, Antarctic Bottom Water (AABW) formation appears to have drastically slowed around $404 \mathrm{ka}$, suggesting a decrease in sea ice and winds from around Antarctica as the Southern Hemisphere warmed (Hall et al., 2001).

At U1345, diversity is highest around $400 \mathrm{ka}$, due to the multiple contributions of Arctic species (freshwater, shelf, coastal, sea ice) and common pelagic diatoms, while the North Pacific indicator N. seminae maintains low relative abundances and does not change throughout this interval. No marked increase in illite is observed during this interval in either U1345 or elsewhere on the Bering Slope (Kim et al., 2016) (Fig. 9). However, chlorite, which dominates North Pacific sediments (Ortiz et al., 2012), decreases at $399 \mathrm{ka}$ (Fig. 9), suggesting a reduced Pacific influence. $\mathrm{C}_{\text {org }} / \mathrm{N}$ values began decreasing linearly starting at $409 \mathrm{ka}$, productivity sharply decreases at $406 \mathrm{ka}$, and $\delta^{15} \mathrm{~N}$ values are the most depleted at $405 \mathrm{ka}$, just $1 \mathrm{kyr}$ before a conspicuous peak in $P$. sulcata, a common diatom found in the Bering Strait. Because there is conflicting evidence of both northward and southward flow, we reject the hypothesis of reversed flow through Bering Strait during MIS 11.

\section{Glacial advance}

At its maximum, the Nome River Glaciation is the most extensive glaciation in central Beringia and is dated to Middle Pleistocene. Although it has not been precisely dated, it is likely correlative with late MIS 11 or MIS 10 (Kaufman et al., 1991; Miller et al., 2009). Nome River glaciomarine sediments recording the onset of rapid tidewater glacial advance are found in places such as St. Lawrence Island (Gualtieri and Brigham-Grette, 2001; Hopkins, 1972), the Pribilof Islands
(Hopkins, 1966), the Alaskan Arctic coastal plain (Kaufman and Brigham-Grette, 1993), Kotzebue (Huston et al., 1990), Nome (Kaufman, 1992), and Bristol Bay (Kaufman et al., 2001) (Fig. 1). At these sites glaciers advanced, in some cases more than $200 \mathrm{~km}$, and reached tidewater while eustatic sea level was high (Huston et al., 1990).

Although global sea level was near its maximum, and much of the world was experiencing peak MIS 11 conditions (Candy et al., 2014), there is evidence that the high latitudes were already cooling. At $410 \mathrm{ka}$, insolation at $65^{\circ} \mathrm{N}$ began to decline (Berger and Loutre, 1991), and cooling began at $407 \mathrm{ka}$ in Antarctica, expressed both isotopically and as an expansion of sea ice (Pol, 2011). Millennial-scale cooling events were recorded at Lake Baikal (Prokopenko et al., 2010). By $405 \mathrm{ka}$, there was some evidence globally for ice sheet growth (Milker et al., 2013) as Lake Baikal began to shift towards a dryer, more continental climate (Prokopenko et al., 2010) and productivity declined at Lake El'gygytgyn (Melles et al., 2012).

Solar forcing coupled with a proximal moisture source, the flooded Beringian shelf, drove snow buildup (BrighamGrette et al., 2001; Huston et al., 1990; Pushkar et al., 1999) and glacial advance from coastal mountain systems. Precipitation at Lake El'gygytgyn, just west of the Bering Strait, was 2 to 3 times higher than today at $405 \mathrm{ka}$ (Melles et al., 2012). A similar "snow gun" hypothesis has been invoked for other high-latitude glaciations (Miller and De Vernal, 1992); however, Beringia is uniquely situated. Once sea level began to drop, Beringia became more continental and arid (Prokopenko et al., 2010) and the moisture source for these glaciers was quickly cut off.

Subaerial and glaciofluvial deposits below the Nome River tills and correlative glaciations indicate that Beringian ice, especially from the western Brooks Range, advanced as the climate grew colder. Ice wedges and evidence of permafrost are common (Huston et al., 1990; Pushkar et al., 1999) in sand and gravel deposits later overridden by Nome River till.

If evidence of the Nome River glaciation in central Beringia was present at U1345, we might expect to see evidence of glacial ice rafting. Previous work has suggested that sediments deposited by icebergs should be poorly sorted and skew towards coarser sediments (Nürnberg et al., 1994). Sediments greater than $150 \mu \mathrm{m}$ are likely glacially ice-rafted (St. John, 2008); however, it is not possible to distinguish sediments deposited by glacial versus sea ice on grain size alone (St. John, 2008). Both types of ice commonly carry sand-sized or larger sediments (Nürnberg et al., 1994). Sea ice diatoms should not be found in glacial ice; instead, we would expect glacial ice either to be barren or to carry freshwater diatoms from ice-scoured lake and pond sediments. At U1345, there is a brief coarse interval (405-402 ka) followed by deposition of freshwater diatoms until $394 \mathrm{ka}$.

Although it is tempting to assign this to the Nome River Glaciation, there are too many unknowns including whether the coarse grains were transported by sea ice, glacial ice, 
or some other method. Further work is ongoing to look for the onset of the Nome River Glaciation in both MIS 11 and MIS 13 as well as to distinguish the transport mechanism for these quartz grains.

\section{Turbidite}

The location of Site U1345 on a high interfluve was chosen to minimize the likelihood that sediments could have been transported and deposited here by turbidites or other downslope currents, yet evidence for a turbidite during this interval is very strong. Although there is no evidence of slumping or distorted sediments, clear erosive surfaces, or any structures that would indicate a turbidite during the anomalous interval, there are folded laminations elsewhere in the sediment core (Takahashi et al., 2011). If this interval was a turbidite, we would expect an erosive surface, overlain by clasts and perhaps a coarse sand layer followed by a fining-up sequence. We see intermittent sand layers and small pebbles coupled with a linear increase in the percent clay throughout the interval (Fig. 10). Sediments are poorly sorted throughout the interval, consistent with rapid turbidite deposition and the presence of neritic and freshwater diatoms suggests redeposition of these sediments offshore from shallow water. Sancetta and Robinson (1983) argue that benthic pennate species were transported out of shallow water by rivers and turbidity currents during glacial periods; however, they do not consider ice as a transport mechanism. In this study, we have considered most benthic pennate species as members of either the epontic or both ice ecological niches (von Quillfeldt et al., 2003). However, it is striking that the pattern of benthic pennate species at U1345 is nearly identical to that of the freshwater species.

Although the evidence is strongest for a turbidite, it is unusual to find just one turbidite as we might expect a turbidity flow to exist in the same place for a prolonged period. Further investigation of this and other Bering Sea cores can elucidate how common intervals like this are along the slope and whether there is temporal consistency between deposits. The presence of a turbidite may suggest that the age model for this core needs to be slightly revised; however, there is no evidence of an erosive surface, nor a clear indication that all of the material deposited during this interval is allochthonous. In addition, the presence of a turbidite does not change the overall orbital- and millennial-scale interpretations of this record. Therefore, we choose to keep the age model as is.

\section{Conclusions}

This study aimed to describe orbital- and millennial-scale changes in productivity and sea ice extent in the Bering Sea, specifically at the shelf-slope break Site U1345. We further tested two hypotheses: (1) in Beringia, tidewater glaciers advanced while sea level was high, and (2) Bering Strait throughflow reversed shortly after the MIS 12 glacial termination (Termination $\mathrm{V}$ ).

The interval between MIS 12 and MIS 10 is marked by large changes in productivity but only minor changes in sea ice extent at Site U1345. Productivity changed in concert with changes in insolation and water temperature. During warmer periods, high stratification appears to have led to lowered productivity. Site U1345 is situated in the presentday oxygen minimum zone, and the presence of laminations frequently throughout the core indicates that oxygen is low. Evidence of denitrification is prevalent for much of the record, likely due to dysoxic conditions.

During MIS 12, productivity was low and seasonal sea ice dominated the Bering Sea, with highly stratified waters during the ice-melt season. At Termination V, diatom productivity increased by 2 orders of magnitude, while nitrogen utilization decreased. At $423 \mathrm{ka}$, an $11 \mathrm{kyr}$ long laminated interval began. This interval was highly productive for multiple phytoplankton groups. The surface waters were relatively unstratified, and sea ice, though still present, decreased. This period is marked by the highest terrigenous organic matter input of the record possibly due to scouring of the continental shelf as sea level rose. During peak and late MIS 11, SSTs appear to have been warm, but seasonal sea ice lasted longer. In addition, at the end of MIS 11, sea ice increased as sea level declined.

Laminations at the end of MIS 11 correspond to millennial-scale stadials seen in the N Atlantic. These deposits represent possible evidence of teleconnections between the Atlantic and the Pacific as eustatic sea level fluctuated near the Bering Strait sill depth.

Decreased NADW formation and species transport from the Arctic Ocean southward support a reversal of the Bering Strait Current at $405 \mathrm{ka}$; however, there is no evidence for the transport of Arctic Ocean clay minerals or oceanographic forcing related to an increase in winds in Antarctica. Therefore, there is inconclusive evidence for a reversal of the Bering Strait Current during MIS 11.

When global sea level was at its maximum, insolation dropped and Beringia began to cool in sync with other polar regions. Sediments deposited during the so-called "anomalous interval" may have been carried by tidewater glaciers bringing neritic species far offshore. This glacial advance is attributed to humid conditions in Beringia that allowed rapid glacial growth. Alternatively, this interval may be a turbidite which could shift the age model for this core and cause this section to be omitted from the paleoceanographic record.

Previous studies have referred to MIS 11 as an analog for the next century of climate change. Today, sea ice barely reaches Site U1345 even in winter and does not reach any other Bering Sea or North Pacific sites (U1340, U1341, U1343 or ODP 884). In contrast, during MIS 11, sea ice diatoms are present throughout the entirety of MIS 11 at U1345 and seasonal sea ice appears to have reached both slope sites and the eastern Bowers Ridge (Onodera et al., 
2016; Stroynowski et al., 2015; Teraishi et al., 2016). However, evidence for a reduction of sea ice in the Arctic Ocean during MIS 11 (Cronin et al., 2013) implies that while winter sea ice was expanded in the Bering Sea compared to today, summer sea ice was likely reduced. Such a significant difference may indicate that MIS 11 is not an ideal analog for climate change over the next 100 years.

However, there are lessons to be learned from the paleorecord. When sea ice declined during early MIS 11, nutrients were upwelled from the deep Bering Sea and flooding of the land bridge further brought nutrients into the surface waters. This caused productivity to increase at sites U1345 and U1343. However, at Bowers Ridge Site U1341, productivity declined at this time. The pattern of primary productivity across the Bering Sea underscores that understanding the myriad drivers of primary productivity is essential as we prepare for decreased sea ice in the future.

\section{Data availability}

All data collected for this publication is archived at the National Center for Environmental Information (Caissie et al., 2016).

\section{The Supplement related to this article is available online at doi:10.5194/cp-12-1739-2016-supplement.}

Acknowledgements. The authors thank the captain and crew of the JOIDES Resolution and Expedition 323 co-chief scientists Christina Ravelo and Kozo Takahashi. We acknowledge the two reviewers, Thomas Cronin and Jason Addison, who provided us with thoughtful comments that greatly improved this manuscript. This work was partially supported by the National Science Foundation, Office of Polar Programs (Arctic Natural Sciences: award \#1023537), and a Post-Expedition Award from the Consortium for Ocean Leadership.

Edited by: L. Beaufort

Reviewed by: T. Cronin and J. Addison

\section{References}

Aizawa, C., Tanimoto, M., and Jordan, R. W.: Living diatom assemblages from North Pacific and Bering Sea surface waters during summer 1999, Deep-Sea Res. Pt. I, 52, 2186-2205, 2005.

Alexander, V. and Chapman, T.: The role of epontic algal communities in Bering Sea ice, in: The Eastern Bering Sea Shelf: Oceanography and Resources, edited by: Hood, D. W. and Calder, J. A., University of Washington Press, Seattle, Washington, 1981.

Asahi, H., Kender, S., Ikehara, M., Sakamoto, T., Takahashi, K., Ravelo, A. C., Alvarez Zarikian, C. A., Khim, B. K., and Leng,
M. J.: Orbital-scale benthic foraminiferal oxygen isotope stratigraphy at the northern Bering Sea Slope Site U1343 (IODP Expedition 323) and its Pleistocene paleoceanographic significance, Deep-Sea Res. Pt. II, 125/126, 66-83, 2016.

Barr, I. D. and Clark, C. D.: Distribution and pattern of moraines in Far NE Russia reveal former glacial extent, Journal of Maps, 5, 186-193, 2009.

Barron, J. A., Bukry, D., Dean, W. E., Addison, J. A., and Finney, B.: Paleoceanography of the Gulf of Alaska during the past 15,000 years: results from diatoms, silicoflagellates, and geochemistry, Mar. Micropaleontol., 72, 176-195, 2009.

Bauch, H. A., Erlenkeuse, H., Helmke, J. P., and Struck, U.: A paleoclimatic evaluatioun of marine oxygen isotope stage 11 in thehigh-northern Atlantic (Nordic seas), Global Planet. Change, 24, 27-39, 2000.

Berger, A. and Loutre, M. F.: Insolation Values for the Climate of the Last 10 Million Years, Quaternary Sci. Rev., 10, 297-317, 1991.

Bertrand, P., Pedersen, T. F., Martinez, P., Calvert, S., and Shimmield, G.: Sea level impact on nutrient cycling in coastal upwelling areas during deglaciation: evidence from nitrogen isotopes, Global Biogeochem. Cy., 14, 341-355, 2000.

Bowen, D. Q.: Sea level 400000 years ago (MIS 11): analogue for present and future sea-level?, Clim. Past, 6, 19-29, doi:10.5194/cp-6-19-2010, 2010.

Brigham-Grette, J., Hopkins, D. M., Ivanov, V. F., Basilyan, A. E., Benson, S. L., Heiser, P. A., and Pushkar, V. S.: Last interglacial (isotope stage 5) glacial and sea-level history of coastal Chukotka Peninsula and St. Lawrence Island, Western Beringia, Quaternary Sci. Rev., 20, 419-436, 2001.

Brunelle, B. G., Sigman, D. M., Cook, M. S., Keigwin, L., Haug, G. H., Plessen, B., Schettler, G., and Jaccard, S. L.: Evidence from diatom-bound nitrogen isotopes for subarctic $\mathrm{Pa}-$ cific stratification during the last ice age and a link to North Pacific denitrification changes, Paleoceanography, 22, PA1215, doi:10.1029/2005pa001205, 2007.

Caissie, B. E.: Diatoms as recorders of sea ice in the Bering and Chukchi seas: proxy development and application, $\mathrm{PhD}$, Geosciences, University of Massachusetts Amherst, Amherst, MA, 190 pp., 2012.

Caissie, B. E., Brigham-Grette, J., Lawrence, K. T., Herbert, T. D., and Cook, M. S.: Last Glacial Maximum to Holocene sea surface conditions at Umnak Plateau, Bering Sea, as inferred from diatom, alkenone, and stable isotope records, Paleoceanography, 25, PA1206, doi:10.1029/2008pa001671, 2010.

Caissie, B. E., Brigham-Grette, J., Cook, M. S., and ColmeneroHidalgo, E.: Navarin Canyon, Bering Sea Diatom, Geochemistry, Grain size, Nannofossils and Mineralogy Data during Marine Isotope Stages 10 to 12, National Centers for Environmental Information, NESDIS, NOAA, US Department of Commerce, https://www.ncdc.noaa.gov/paleo/study/20326, 2016.

Candy, I., Schreve, D. C., Sherriff, J., and Tye, G. J.: Marine Isotope Stage 11: Palaeoclimates, palaeoenvironments and its role as an analogue for the current interglacial, Earth-Sci. Rev., 128, 18-51, 2014.

Cavalieri, D. J., Parkinson, P., Gloersen, P., and Zwally: Sea Ice Concentrations from Nimbus-7 SMMR and DMSP SSM/I Passive Microwave Data, 1996-2008, National Snow and Ice Data Center, Boulder, CO, 1996. 
Chaisson, W. P., Poli, M. S., and Thunell, R. C.: Gulf Stream and Western Boundary Undercurrent variations during MIS 10-12 at Site 1056, Blake-Bahama Outer Ridge, Mar. Geol., 189, 79-105, 2002.

Cook, M. S., Ravelo, A. C., Mix, A., Nesbitt, I. M., and Miller, N. V.: Tracing subarctic Pacific water masses with benthic foraminiferal stable isotopes during the LGM and late Pleistocene, Deep-Sea Res. Pt. II, 125/126, 84-95, 2016.

Cooper, L. W., Whitledge, T. E., Grebmeier, J. M., and Wieingartner, T.: The nutrient, salinity, and stable oxygen isotope composition of Bering and Chukchi Seas waters in and near the Bering Strait, J. Geophys. Res., 102, 12563-12573, 1997.

Cronin, T. M., Polyak, L., Reed, D., Kandiano, E. S., Marzen, R. E., and Council, E. A.: A 600-ka Arctic sea-ice record from Mendeleev Ridge based on ostracodes, Quaternary Sci. Rev., 79, 157-167, 2013.

D’Anjou, R. M., Wei, J. H., Castañeda, I. S., Brigham-Grette, J., Petsch, S. T., and Finkelstein, D. B.: High-latitude environmental change during MIS 9 and 11: biogeochemical evidence from Lake El'gygytgyn, Far East Russia, Clim. Past, 9, 567-581, doi:10.5194/cp-9-567-2013, 2013.

DeBoer, A. M. and Nof, D.: The Exhaust Valve of the North Atlantic, J. Clim., 17, 417-422, 2004.

de Vernal, A. and Hillaire-Marcel, C.: Natural variability of Greenland climate, vegetation, and ice volume during the past million years, Science, 320, 1622-1625, 2008.

Dickson, A. J., Beer, C. J., Dempsey, C., Maslin, M. A., Bendle, J. A., McClymont, E. L., and Pancost, R. D.: Oceanic forcing of the Marine Isotope Stage 11 interglacial, Nat. Geosci., 2, 428-433, 2009.

Droxler, A. W., Alley, R. B., Howard, W. R., Poore, R. Z., and Burckle, L. H.: Unique and exceptionally long interglacial Marine Isotope Stage 11: window into Earth's warm future climate, in: Earth's Climate and Orbital Eccentricity: The Marine Isotope Stage 11 Question, edited by: Droxler, A. W., Poore, R. Z., and Burckle, L. H., American Geophysical Union, Washington, DC, 2003.

Dutton, A., Carlson, A. E., Long, A. J., Milne, G. A., Clark, P. U., DeConto, R., Horton, B. P., Rahmstorf, S., and Raymo, M. E.: Sea-level rise due to polar ice-sheet mass loss during past warm periods, Science, 349, AAA4019, doi:10.1126/science.aaa4019, 2015.

Eberl, D. D.: User's Guide to RockJock - a Program for Determining Quantitative Mineralogy from Powder X-Ray Diffraction Data, US Geological Survey, Open-File Report 03-78, Boulder, CO, 2003.

EPICA Community Members: Eight glacial cycles from an Antarctic ice core, Nature, 429, 623-628, 2004.

Flores, J. A. and Sierro, F. J.: Revised technique for calculation of calcareous nannofossil accumulation rates, Micropaleontology, 43, 321-324, 1997.

Flores, J. A., Gersonde, R., and Sierro, F. J.: Pleistocene fluctuations in the Agulhas Current Retroflection based on the calcareous plankton record, Mar. Micropaleontol., 37, 1-22, 1999.

Fryxell, G. A. and Hasle, G. R.: Thalassiosira eccentrica (Ehreb.) Cleve, T. symmetrica sp. nov., and some related centric diatoms, J. Phycol., 8, 297-317, 1972.
Glushkova, O. Y.: Geomorphological correlation of Late Pleistocene glacial complexes of Western and Eastern Beringia, Quaternary Sci. Rev., 20, 405-417, 2001.

Gualtieri, L. and Brigham-Grette, J.: The age and origin of the Little Diomede Island upland surface, Arctic, 54, 12-21, 2001.

Gualtieri, L., Glushkova, O., and Brigham-Grette, J.: Evidence for restricted ice extent during the last glacial maximum in the Koryak Mountains of Chukotka, far eastern Russia, Geol. Soc. Am. Bull., 112, 1106-1118, 2000.

Håkansson, H.: A compilation and evaluation of species in the general Stephanodiscus, Cyclostephanos, and Cyclotella with a new genus in the family Stephanodiscaceae, Diatom Res., 17, 1-139, 2002.

Hall, I. R., McCave, L. N., Shackleton, N. J., Weedon, G. P., and Harris, S. E.: Intensified deep Pacific inflow and ventilation in Pleistocene glacial times, Nature, 412, 809-812, 2001.

Hasle, G. R. and Heimdal, B. R.: Morphology and distribution of the marine centric diatom Thalassiosira antarctica Comber, J. Roy. Micros. Soc., 88, 357-369, 1968.

Hay, M. B., Dallimore, A., Thomson, R. E., Calvert, S. E., and Pienitz, R.: Siliceous microfossil record of late Holocene oceanography and climate along the west coast of Vancouver Island, British Columbia (Canada), Quaternary Res., 67, 33-49, 2007.

Heiser, P. A. and Roush, J. J.: Pleistocene glaciations in Chukotka, Russia: moraine mapping using satellite synthetic aperture radar (SAR) imagery, Quaternary Sci. Rev., 20, 393-404, 2001.

Hopkins, D. M.: Cenozoic History of the Bering Land Bridge, Science, 129, 1519-1528, 1959.

Hopkins, D. M.: Pleistocene glaciation on St. George, Pribilof Islands, Science, 152, 343-345, 1966.

Hopkins, D. M.: The paleogeography and climatic history of Beringia during late Cenozoic Time, Internord, 12, 121-150, 1972.

Horner, R.: Sea Ice Biota, CRC Press, Inc, Boca Raton, FL, 1985.

Hu, A. X., Meehl, G. A., Otto-Bliesner, B. L., Waelbroeck, C., Han, W. Q., Loutre, M. F., Lambeck, K., Mitrovica, J. X., and Rosenbloom, N.: Influence of Bering Strait flow and North Atlantic circulation on glacial sea-level changes, Nat. Geosci., 3, 118-121, 2010.

Huston, M. M., Brigham-Grette, J., and Hopkins, D. M.: Paleogeographic significance of middle Pleistocene glaciomarine deposits on Baldwin Peninsula, northwestern Alaska, Ann. Glaciol., 14, 111-114, 1990.

IPCC: Climate Change 2013: The Physical Science Basis, Contribution of Working Group I to the Fifth Assessment Report of the Intergovernmental Panel on Climate Change, edited by: Stocker, T. F., Qin, D., Plattner, G.-K., Tignor, M., Allen, S. K., Boschung, J., Nauels, A., Xia, Y., Bex, V., and Midgley, P. M., Cambridge University Press, Cambidge, UK and New York, NY, USA, 2013.

Iwasaki, S., Takahashi, K., Kanematsu, Y., Asahi, H., Onodera, J., and Ravelo, A. C.: Paleoproductivity and paleoceanography of the last 4.3 Myrs at IODP Expedition 323 Site U1341 in the Bering Sea based on biogenic opal content, Deep-Sea Res. Pt. II, 125/126, 145-154, 2016.

Kandiano, E. S., Bauch, H. A., Fahl, K., Helmke, J. P., Roehl, U., Perez-Folgado, M., and Cacho, I.: The meridional temperature gradient in the eastern North Atlantic during MIS 11 and 
its link to the ocean-atmosphere system, Palaeogeogr. Palaeocl., 333, 24-39, 2012.

Kanematsu, Y., Takahashi, K., Kim, S., Asahi, H., and Khim, B.K.: Changes in biogenic opal productivity with Milankovitch cycles during the last 1.3 Ma at IODP Expedition 323 Sites U1341, U1343, and U1345 in the Bering Sea, Quatern. Int., 310, 213220, 2013.

Kariya, C., Hyodo, M., Tanigawa, K., and Sato, H.: Sea-level variation during MIS 11 constrained by stepwise Osaka Bay extensions and its relation with climatic evolution, Quaternary Sci. Rev., 29, 1863-1879, 2010.

Kato, Y., Onodera, J., Suto, I., Teraishi, A., and Takahashi, K.: Pliocene and Pleistocene paleoceanography in the western subarctic Pacific based on diatom analyses of ODP Leg 145 Hole 884B and IODP Expedition 323 Holes U1341B and U1343E, Deep-Sea Res. Pt. II, 125/126, 29-37, 2016.

Katsuki, K. and Takahashi, K.: Diatoms as paleoenvironmental proxies for seasonal productivity, sea-ice and surface circulation in the Bering Sea during the late Quaternary, Deep-Sea Res. Pt. II, 52, 2110-2130, 2005.

Kaufman, D., Young, N. E., Briner, J. P., and Manley, W. F.: Alaska Palaeo-Glacier Atlas (Version 2), in: Developments in Quaternary Science, edited by: Ehlers, J., Gibbard, P. L., and Hughes, P. D., Amsterdam, the Netherlands, 2011.

Kaufman, D. S.: Aminostratigraphy of Pliocene-Pleistocene highsea-level deposits, Nome coastal plain and adjacent nearshore area, Alaska, Geol. Soc. Am. Bull., 104, 40-52, 1992.

Kaufman, D. S. and Brigham-Grette, J.: Aminostratigraphic correlations and paleotemperature implications, Pliocene-Pleistocene high sea-level deposits, Northwestern Alaska, Quaternary Sci. Rev., 12, 21-33, 1993.

Kaufman, D. S., Walter, R. C., Brigham-Grette, J., and Hopkins, D. M.: Middle Pleistocene age of the Nome River glaciation, northwestern Alaska, Quaternary Res., 36, 277-293, 1991.

Kaufman, D. S., Manley, W. F., Forman, S. L., and Layer, P. W.: Pre-Late-Wisconsin glacial history, coastal Ahklun Mountains, southwestern Alaska - new amino acid, thermoluminescence, and ${ }^{40} \mathrm{Ar} /{ }^{39} \mathrm{Ar}$ results, Quaternary Sci. Rev., 20, 337-352, 2001.

Keigwin, L. D., Donnelly, J. P., Cook, M. S., Driscoll, N. W., and Brigham-Grette, J.: Rapid sea-level rise and Holocene climate in the Chukchi Sea, Geology, 34, 861-864, 2006.

Kim, S., Khim, B. K., and Goo Cho, H.: Clay mineral stratigraphy during the last 2.4 Ma at IODP Exp. 323 Site U1343 in the Bering Sea, Mar. Geol., 359, 163-168, 2015.

Kim, S., Khim, B.-K., and Takahashi, K.: Late Pliocene to early Pleistocene (2.4-1.25 Ma) paleoproductivity changes in the Bering Sea: IODP expedition 323 Hole U1343E, Deep-Sea Res. Pt. II, 125/126, 155-162, 2016.

Kindler, P. and Hearty, P. J.: Elevated marine terraces from Eleuthera (Bahamas) and Bermuda: sedimentological, petrographic, and geochronological evidence for important deglaciation events during the middle Pleistocene, Global Planet. Change, 24, 41-58, 2000.

Kleinen, T., Hildebrandt, S., Prange, M., Rachmayani, R., Mueller, S., Bezrukova, E., Brovkin, V., and Tarasov, P. E.: The climate and vegetation of Marine Isotope Stage 11-Model results and proxy-based reconstructions at global and regional scale, Quatern. Int., 348, 247-265, 2014.
Knudson, K. P. and Ravelo, A. C.: North Pacific Intermediate Water circulation enhanced by the closure of the Bering Strait, Paleoceanography, 30, 1287-1304, 2015.

Koizumi, I.: The Late Cenozoic diatoms of Sites 183-193, Leg 19 Deep-Sea Drilling Project, Initial Reports of the Deep-Sea Drilling Project, 19, 805-855, 1973.

Kowalik, Z.: Bering Sea Tides, in: Dynamics of the Bering Sea, edited by: Loughlin, T. R. and Ohtani, K., Universtiy of Alaska Sea Grant, Fairbanks, AK, 1999.

Lisiecki, L. E. and Raymo, M. E.: A Pliocene-Pleistocene stack of 57 globally distributed benthic delta O-18 records, Paleoceanography, 20, PA1003, doi:10.1029/2004PA001071, 2005.

Liu, Z. H., Altabet, M. A., and Herbert, T. D.: Glacial-interglacial modulation of eastern tropical North Pacific denitrification over the last 1.8-Myr, Geophys. Res. Lett., 32, L23607, doi:10.1029/2005GL024439, 2005.

Lopes, C., Mix, A. C., and Abrantes, F.: Diatoms in northeast Pacific surface sediments as paleoceanographic proxies, Mar. Micropaleontol., 60, 45-65, 2006.

Loutre, M. F. and Berger, A.: Marine Isotope Stage 11 as an analogue for the present interglacial, Global Planet. Change, 36, 209-217, 2003.

Lozhkin, A. V. and Anderson, P. M.: Vegetation responses to interglacial warming in the Arctic: examples from Lake El'gygytgyn, Far East Russian Arctic, Clim. Past, 9, 1211-1219, doi:10.5194/cp-9-1211-2013, 2013.

Lundholm, N. and Hasle, G. R.: Are Fragilariopsis cylindrus and Fragilariopsis nana bipolar diatoms? Morphological and molecular analyses of two sympatric species, Nova Hedwigia, 133, 231-250, 2008.

Lundholm, N. and Hasle, G. R.: Fragilariopsis (Bacillariophyceae) of the Northern Hemisphere-morphology, taxonomy, phylogeny and distribution, with a description of $F$. pacifica sp. nov., Phycologia, 49, 438-460, 2010.

Lyle, M., Heusser, L., Herbert, T., Mix, A. C., and Barron, J.: Interglacial theme and variations: 500 k.y. of orbital forcing and associated responses from the terrestrial and marine biosphere, US Pacific Northwest, Geology, 29, 1115-1118, 2001.

Manley, W. F.: Digital Elevation Model (DEM) for the Bering Land Bridge, INSTAAR, University of Colorado, Boulder, CO, 2002.

Maurer, B. A. and McGill, B. J.: Chapter 5: measurement of species diversity, in: Biological Diversity, edited by: Magurran, A. E. and McGill, B. J., Oxford University Press, New York, 2011.

McKay, R., Naish, T., Powell, R., Barrett, P., Scherer, R., Talarico, F., Kyle, P., Monien, D., Kuhn, G., Jackolski, C., and Williams, T.: Pleistocene variability of Antarctic Ice Sheet extent in the Ross Embayment, Quaternary Sci. Rev., 34, 93-112, 2012.

McManus, J., Oppo, D. W., Cullen, J. L., and Healey, S.: Marine Isotope Stage 11 (MIS 11): analog for Holocene and future climate, in: Earth's Climate and Orbital Eccentricity: The Marine Isotope Stage 11, edited by: Droxler, A. W., Poore, R. Z., and Burkle, L. H., Geophysical Monograph 137, American Geophysical Union, Washington, DC, 2003.

McQuoid, M. R. and Hobson, L. A.: A Holocene record of diatom and silicoflagellate microfossils in sediments of Saanich Inlet, ODP Leg 169S, Mar. Geol., 174, 111-123, 2001.

Medlin, L. K. and Hasle, G. R.: Some Nitzschia and related diatom species from fast ice samples in the Arctic and Antarctic, Polar Biol., 10, 451-479, 1990. 
Medlin, L. K. and Priddle, J.: Polar Marine Diatoms, British Antarctic Survey, Natural Environment Research Council, Cambridge, 1990.

Melles, M., Brigham-Grette, J., Minyuk, P., Nowaczyk, N. R., Wennrich, V., DeConto, R. M., Anderson, P. M., Andreev, A. A., Coletti, A., Cook, T. L., Haltia-Hovi, E., Kukkonen, M., Lozhkin, A. V., Rosen, P., Tarasov, P. E., Vogel, H., and Wagner, B.: 2.8 Million years of Arctic climate change from Lake El'gygytgyn, NE Russia, Science, 337, 315-320, 2012.

Meyers, P. A.: Preservation of elemental and isotopic source identification of sedimentary organic matter, Chem. Geol., 114, 289302, 1994

Milker, Y., Rachmayani, R., Weinkauf, M. F. G., Prange, M., Raitzsch, M., Schulz, M., and Kucera, M.: Global and regional sea surface temperature trends during Marine Isotope Stage 11, Clim. Past, 9, 2231-2252, doi:10.5194/cp-9-2231-2013, 2013.

Miller, G. H. and De Vernal, A.: Will greenhouse warming lead to Northern Hemisphere ice-sheet growth?, Nature, 355, 244-246, 1992.

Miller, G. H., Brigham-Grette, J., Anderson, L., Bauch, H. A., Douglas, M. A., Edwards, M. E., Elias, S. A., Finney, B. P., Funder, S., Herbert, T., Hinzman, L. D., Kaufman, D. K., MacDonald, G. M., Robock, A., Serreze, M. C., Smol, J. P., Spielhagen, R. F., Wolfe, A. P., and Wolff, E. W.: Temperature and precipitation history of the Arctic, in: Past Climate Variability and Change in the Arctic and at High Latitudes, edited by: US Climate Change Program and Subcommittee on Global Change Research, US Geological Survey, Reston, VA, 77-246, 2009.

Muller, P. J.: C-N Ratios in Pacific Deep-Sea Sediments - Effect of Inorganic Ammonium and Organic Nitrogen Compounds Sorbed by Clays, Geochim. Cosmochim. Ac., 41, 765-776, 1977.

Naish, T., Powell, R., Levy, R., Wilson, G., Scherer, R., Talarico, F., Krissek, L., Niessen, F., Pompilio, M., Wilson, T., Carter, L., DeConto, R., Huybers, P., McKay, R., Pollard, D., Ross, J., Winter, D., Barrett, P., Browne, G., Cody, R., Cowan, E., Crampton, J., Dunbar, G., Dunbar, N., Florindo, F., Gebhardt, C., Graham, I., Hannah, M., Hansaraj, D., Harwood, D., Helling, D., Henrys, S., Hinnov, L., Kuhn, G., Kyle, P., Laufer, A., Maffioli, P., Magens, D., Mandernack, K., McIntosh, W., Millan, C., Morin, R., Ohneiser, C., Paulsen, T., Persico, D., Raine, I., Reed, J., Riesselman, C., Sagnotti, L., Schmitt, D., Sjunneskog, C., Strong, P., Taviani, M., Vogel, S., Wilch, T., and Williams, T.: Obliquity-paced Pliocene West Antarctic ice sheet oscillations, Nature, 458, 322384, 2009.

Normack, W. R. and Carlson, P. R.: Giant submarine canyons: is size any clue to their importance in the rock record?, in: Geological Society of America Special Paper, edited by: Chan, M. A. and Archer, A. W., Geological Society of America, Boulder, CO, 2003.

Nürnberg, D., Wollenburg, I., Dethleff, D., Eicken, H., Kassens, H., Letzig, T., Reimnitz, E., and Thiede, J.: Sediments in Arctic SeaIce - Implications for Entrainment, Transport and Release, Mar. Geol., 119, 185-214, 1994.

Onodera, J. and Takahashi, K.: Diatoms and siliceous flagellates (silicoflagellates, ebridians, and endoskeletal dinoflagellate Actiniscus) from the Subarctic Pacific, Memoirs of the Faculty of Sciences Kyushu University., Series D, Earth Planet. Sci., 31, 105-136, 2007.
Onodera, J., Takahashi, K., and Nagatomo, R.: Diatoms, silicoflagellates, and ebridians at Site U1341 on the western slope of Bowers Ridge, IODP Expedition 323, Deep-Sea Res. Pt. II, 125/126, 8-17, 2016.

Ortiz, J. D., Nof, D., Polyak, L., St-Onge, G., Lisé-Pronovost, A., Naidu, S., Darby, D., and Brachfeld, S.: The Late Quaternary Flow through the Bering Strait Has Been Forced by the Southern Ocean Winds, J. Phys. Oceanogr., 42, 2014-2029, 2012.

PAGES Past Interglacials Working Group, P. I. W. G. o., Berger, A., Crucifix, M., Hodell, D. A., Mangili, C., McManus, J. F., OttoBliesner, B., Pol, K., Raynaud, D., Skinner, L. C., Tzedakis, P. C., Wolff, E. W., Yin, Q. Z., Abe-Ouchi, A., Barbante, C., Brovkin, V., Cacho, I., Capron, E., Ferretti, P., Ganopolski, A., Grimalt, J. O., Hoenisch, B., Kawamura, K., Landais, A., Margari, V., Martrat, B., Masson-Delmotte, V., Mokeddem, Z., Parrenin, F., Prokopenko, A. A., Rashid, H., Schulz, M., and Riveiros, N. V.: Interglacials of the last 800,000 years, Rev. Geophys., 54, 162219, 2016.

Perdue, E. M. and Koprivnjak, J.-F.: Using the $\mathrm{C} / \mathrm{N}$ ratio to estimate terrigenous inputs of organic matter to aquatic environments, Estuar. Coast. Shelf S, 73, 65-72, 2007.

Pol, K., Debret, M., Masson-Delmotte, V., Capron, E., Cattani, O., Dreyfus, G., Falourd, S., Johnsen, S., Jouzel, J., Landais, A., Minster, B., and Stenni, B.: Links between MIS 11 millennial to sub-millennial climate variability and long term trends as revealed by new high resolution EPICA Dome $\mathrm{C}$ deuterium data - A comparison with the Holocene, Clim. Past, 7, 437-450, doi:10.5194/cp-7-437-2011, 2011.

Poli, M. S., Meyers, P. A., and Thunell, R. C.: The western North Atlantic record of MIS 13 to 10: Changes in primary productivity, organic carbon accumulation and benthic foraminiferal assemblages in sediments from the Blake Outer Ridge (ODP Site 1058), Palaeogeogr. Palaeocl., 295, 89-101, 2010.

Pollard, D. and DeConto, R. M.: Modelling West Antarctic ice sheet growth and collapse through the past five million years, Nature, 458, 329-389, 2009.

Prokopenko, A. A., Bezrukova, E. V., Khursevich, G. K., Solotchina, E. P., Kuzmin, M. I., and Tarasov, P. E.: Climate in continental interior Asia during the longest interglacial of the past 500000 years: the new MIS 11 records from Lake Baikal, SE Siberia, Clim. Past, 6, 31-48, doi:10.5194/cp-6-312010, 2010.

Pushkar, V. S., Roof, S. R., Cherepanova, M. V., Hopkins, D. M., and Brigham-Grette, J.: Paleogeographic and paleoclimatic significance of diatoms from Middle Pleistocene marine and glaciomarine deposits on Baldwin Peninsula, northwestern Alaska, Palaeogeogr. Palaeocl., 152, 67-85, 1999.

Raymo, M. E. and Mitrovica, J. X.: Collapse of polar ice sheets during the stage 11 interglacial, Nature, 483, 453-456, 2012.

Raymo, M. E., Mitrovica, J. X., O’Leary, M. J., DeConto, R. M., and Hearty, P. J.: Departures from eustasy in Pliocene sea-level records, Nat. Geosci., 4, 328-332, 2011.

Raynaud, D., Barnola, J. M., Souchez, R., Lorrain, R., Petit, J. R., Duval, P., and Lipenkov, V. Y.: The record for Marine Isotopic Stage 11, Nature, 436, 39-40, 2005.

Redfield, A. C., Ketchum, B. H., and Richards, F. A.: The inuence of organisms on the composition of sea water, in: The Sea, edited by: Hill, M. N., Wiley, New York, 1963. 
Reimnitz, E., McCormick, M., Bischof, J., and Darby, D. A.: Comparing sea-ice sediment load with Beaufort Sea shelf deposits: is entrainment selective?, J. Sediment. Res., 68, 777-787, 1998.

Reyes, A. V., Carlson, A. E., Beard, B. L., Hatfield, R. G., Stoner, J. S., Winsor, K., Welke, B., and Ullman, D. J.: South Greenland ice-sheet collapse during Marine Isotope Stage 11, Nature, 510, 525-528, 2014.

Rohling, E. J., Braun, K., Grant, K., Kucera, M., Roberts, A. P., Siddall, M., and Trommer, G.: Comparison between Holocene and Marine Isotope Stage-11 sea-level histories, Earth Plane. Sci. Lett., 291, 97-105, 2010.

Rohling, E. J., Foster, G. L., Grant, K. M., Marino, G., Roberts, A. P., Tamisiea, M. E., and Williams, F.: Sea-level and deep-seatemperature variability over the past 5.3 million years, Nature, 510, 432-432, 2014

Saito, K. and Taniguchi, A.: Phytoplankton communities in the Bering Sea and adjacent seas II: spring and summer communities in seasonally ice-covered areas, Astarte, 11, 27-35, 1978.

Sancetta, C. A.: Oceanographic and ecologic significance of diatoms in surface sediments of the Bering and Okhotsk seas, Deep-Sea Res. Pt. A, 28, 789-817, 1981.

Sancetta, C. A.: Distribution of diatom species in surface sediments of the Bering and Okhotsk seas, Micropaleontology, 28, 221257, 1982

Sancetta, C. A. and Robinson, S. W.: Diatom evidence on Wisconsin and Holocene events in the Bering Sea, Quaternary Res., 20, 232-245, 1983.

Sancetta, C. A.: Three species of Coscinodiscus Ehrenberg from North Pacific sediments examined in the light and scanning electron microscopes, Micropaleontology, 33, 230-241, 1987.

Sancetta, C. A. and Silvestri, S. M.: Pliocene-Pleistocene evolution of the North Pacific ocean-atmosphere system, interpreted from fossil diatoms, Paleoceanography, 1, 163-180, 1986.

Schandelmeier, L. and Alexander, V.: An analysis of the influence of ice on spring phytoplankton population structure in the southeast Bering Sea, Limnol. Oceanogr., 26, 935-943, 1981.

Scherer, R. P.: A new method for the determination of absolute abundance of diatoms and other silt-sized sedimentary particles, J. Paleolimnol., 12, 171-179, 1994.

Scherer, R. P., Aldahan, A., Tulaczyk, S., Possnert, G., Engelhardt, H., and Kamb, B.: Pleistocene collapse of the West Antarctic Ice Sheet, Science, 281, 82-85, 1998.

Schlung, S. A., Ravelo, A. C., Aiello, I. W., Andreasen, D. H., Cook, M. S., Drake, M., Dyez, K. A., Guilderson, T. P., LaRiviere, J. P., Stroynowski, Z., and Takahashi, K.: Millennial-scale climate change and intermediate water circulation in the Bering Sea from 90 ka: A high-resolution record from IODP Site U1340, Paleoceanography, 28, 54-67, 2013.

Schrader, H. J. and Gersonde, R.: Diatoms and silicoflagellates. In: Micropaleontological counting methods and techniques - an exercise on an eight metres section of the Lower Pliocene of Capo Rossello, Sicily, edited by: Zachariasse, W. J., Riedel, W. R., Sanfilippo, A., Schmidt, R. R., Brolsma, M. J., Schrader, H. J., Gersonde, R., Drooger, M. M., and Broekman, J. A., Utrecht Micropaleontological Bulletin, Netherlands, 1978.

Schubert, C. J. and Calvert, S. E.: Nitrogen and carbon isotopic composition of marine and terrestrial organic matter in Arctic Ocean sediments: implications for nutrient utilization and or- ganic matter composition, Deep-Sea Res. Pt. I, 48, 789-810, 2001.

Schumacher, J. D. and Stabeno, P. J.: Continental shelf of the Bering Sea, in: The sea, edited by: Robinson, A. R. and Brink, K. H., John Wiley and Sons, New York, 1998.

Shiga, K. and Koizumi, I.: Latest Quaternary oceanographic changes in the Okhotsk Sea based on diatom records, Mar. Micropaleontol., 38, 91-117, 2000.

Sigman, D., Altabet, M., Francois, R., McCorkle, D., and Gaillard, J.-F.: The isotopic composition of diatom-bound nitrogen in Southern Ocean sediments, Paleoceanography, 14, 118-134, 1999.

Smol, J. P.: The paleolimnologist's Rosetta Stone: calibrating indicators to environmental variables using surface-sediment training sets, in: Pollution of lakes and rivers: a paleoenvironmental perspective, edited by: Smol, J. P., Key issues in environmental change, Oxford University Press, New York, 2002.

Springer, A. M., McRoy, C. P., and Flint, M. V.: The Bering Sea green belt: shelf edge processes and ecosystem production, Fish. Oceanogr., 5, 205-223, 1996.

Stabeno, P. J., Schumacher, J. D., and Ohtani, K.: The physical oceanography of the Bering Sea, in: Dynamics of the Bering Sea: a summary of physical, chemical, and biological characteristics, and a synopsis of research on the Bering Sea, edited by: Loughlin, T. R. and Ohtani, K., University of Alaska Sea Grant, Fairbanks, AK, 1999.

St. John, K.: Cenozoic ice-rafting history of the central Arctic Ocean: Terrigenous sands on the Lomonosov Ridge, Paleoceanography, 23, PA1S05, doi:10.1029/2007pa001483, 2008.

Stroynowski, Z., Ravelo, A. C., and Andreasen, D.: A Pliocene to recent history of the Bering Sea at Site U1340A, IODP Expedition 323, Paleoceanography, 30, 1641-1656, 2015.

Syvertsen, E. E.: Resting Spore Formation in Clonal Cultures of Thalassiosira antarctica Comber, T. nordenskioeldii Cleve and Detonula confervacea (Cleve) Gran, Nova Hedwigia, 64, 41-63, 1979.

Takahashi, K., Ravelo, A. C., Alvarez Zarikian, C. A., and Scientists, E.: Proceedings of the Integrated Ocean Drilling Program, Tokyo, 2011.

Tarasov, P. E., Nakagawa, T., Demske, D., Österle, H., Igarashi, Y., Kitagawa, J., Mokhova, L., Bazarova, V., Okuda, M., Gotanda, K., Miyoshi, N., Fujiki, T., Takemura, K., Yonenobu, H., and Fleck, A.: Progress in the reconstruction of Quaternary climate dynamics in the Northwest Pacific: A new modern analogue reference dataset and its application to the 430-kyr pollen record from Lake Biwa, Earth-Sci. Rev., 108, 64-79, 2011.

Teitler, L., Florindo, F., Warnke, D. A., Filippelli, G. M., Kupp, G., and Taylor, B.: Antarctic Ice Sheet response to a long warm interval across Marine Isotope Stage 31: A cross-latitudinal study of iceberg-rafted debris, Earth Planet. Sci. Lett., 409, 109-119, 2015.

Teraishi, A., Suto, I., Onodera, J., and Takahashi, K.: Diatom, silicoflagellate and ebridian biostratigraphy and paleoceanography in IODP 323 Hole U1343E at the Bering slope site, Deep-Sea Res. Pt. II, 125/126, 18-28, 2016.

Ternois, Y., Kawamura, K., Keigwin, L., Ohkouchi, N., and Nakatsuka, T.: A biomarker approach for assessing marine and terrigenous inputs to the sediments of Sea of Okhotsk for the last 27,000 years, Geochim. Cosmochim. Ac., 65, 791-802, 2001. 
Tomas, C. R.: Identifying marine diatoms and dinoflagellates, Academic Press, Inc. Harcourt Brace and Co., Boston, USA, 1996.

Tzedakis, P. C.: The MIS 11 -MIS 1 analogy, southern European vegetation, atmospheric methane and the "early anthropogenic hypothesis", Clim. Past, 6, 131-144, doi:10.5194/cp-6131-2010, 2010.

van Hengstum, P. J., Scott, D. B., and Javaux, E. J.: Foraminifera in elevated Bermudian caves provide further evidence for $+21 \mathrm{~m}$ eustatic sea level during Marine Isotope Stage 11, Quaternary Sci. Rev., 28, 1850-1860, 2009.

Voelker, A. H. L., Rodrigues, T., Billups, K., Oppo, D., McManus, J., Stein, R., Hefter, J., and Grimalt, J. O.: Variations in midlatitude North Atlantic surface water properties during the midBrunhes (MIS 9-14) and their implications for the thermohaline circulation, Clim. Past, 6, 531-552, doi:10.5194/cp-6-531-2010, 2010.

Vogel, H., Meyer-Jacob, C., Melles, M., Brigham-Grette, J., Andreev, A. A., Wennrich, V., Tarasov, P. E., and Rosén, P.: Detailed insight into Arctic climatic variability during MIS 11c at Lake El'gygytgyn, NE Russia, Clim. Past, 9, 1467-1479, doi:10.5194/cp-9-1467-2013, 2013. von Quillfeldt, C. H.: Identification of some easily confused common diatom species in Arctic spring blooms, Bot. Mar., 44, 375389, 2001.

von Quillfeldt, C. H., Ambrose, W. G. J., and Clough, L. M.: High number of diatom species in first-year ice from the Chukchi Sea, Polar Biol., 26, 806-818, 2003.

Walinsky, S. E., Prahl, F. G., Mix, A. C., Finney, B. P., Jaeger, J. M., and Rosen, G. P.: Distribution and composition of organic matter in surface sediments of coastal Southeast Alaska, Cont. Shelf Res., 29, 1565-1579, 2009.

Witkowski, A., Lange-Bertalot, H., and Metzeltin, D.: Diatom Flora of Marine Coasts I, A.R.G. Gantner Verlag K.G., Ruggell, Liechtenstein, 2000.

Young, J. R., Geisen, M., Cros, L., Keleijne, A., Sprengel, C., Probert, I., and Østengaard, J.: A guide to extant coccolithophore taxonomy, J. Nannoplank. Res., 1, 1-125, 2003. 